University of Rhode Island

DigitalCommons@URI

Open Access Master's Theses

1992

\title{
An Intellectual History of the Common Heritage of Mankind as Applied to the Oceans
}

Monica Allen

University of Rhode Island

Follow this and additional works at: https://digitalcommons.uri.edu/theses

\section{Recommended Citation}

Allen, Monica, "An Intellectual History of the Common Heritage of Mankind as Applied to the Oceans" (1992). Open Access Master's Theses. Paper 1088.

https://digitalcommons.uri.edu/theses/1088

This Thesis is brought to you for free and open access by DigitalCommons@URI. It has been accepted for inclusion in Open Access Master's Theses by an authorized administrator of DigitalCommons@URI. For more information, please contact digitalcommons-group@uri.edu. 


\author{
AN INTELLECTUAL HISTORY OF \\ THE COMMON HERITAGE OF \\ MANKIND AS APPLIED TO THE \\ OCEANS \\ BY \\ MONICA ALLEN
}

A THESIS SUBMITTED IN PARTIAL FULFILLMENT OF THE

REQUIREMENTS FOR THE DEGREE OF

MASTER OF ARTS

IN

MARINE AFFAIRS

UNIVERSITY OF RHODE ISLAND

1992 


\title{
MASTER OF ARTS THESIS
}

OF

\author{
MONICA ALLEN
}

\section{APPROVED:}

Thesis Committee

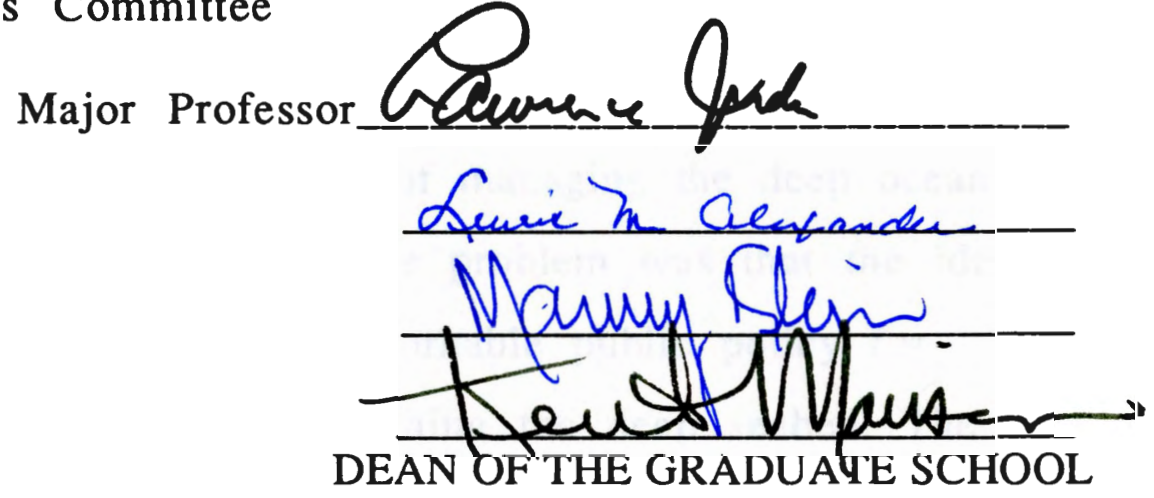

UNIVERSITY OF RHODE ISLAND

1992 


\section{Abstract}

This thesis traces the development of the concept of the common heritage of mankind from its introduction by Arvid Pardo, the Ambassador to the United Nations from Malta, in 1967 to its translation into policy in the 1982 Third United Nations Convention on the Law of the Sea. The thesis pays particular attention to the people and ideas that influenced Pardo and the historical period of the late 1960s in which the common heritage idea for the deep seabed was articulated. It was a period of international idealism and a brief period in which the United States President, Lyndon Johnson, lent his grandiose rhetoric to the idea of managing the deep oceans as a common heritage. However, the problem was that the idea could not be translated into workable public policy for international cooperation in mining the deep seabed. The idea became a vehicle for a number of groups and individuals including the Third World nations that wanted to make it a part of their demands for a new economic order. Although a seabed mining regime was negotiated and is in place in the treaty, the United States and some other developed nations refused to sign the treaty because of the seabed regime. Other events that hurt the process of turning the common heritage idea into workable policy were the decline in demand for minerals and a global recession that made such an expensive enterprise less attractive. 
This thesis is also an examination of how a small group of visionaries were able to promote an idea and place it on a global agenda. Despite the fact that seabed mining has yet to take place and the treaty remains unratified ten years after its completion, the general issues that the common heritage idea raised has not evaporated. International environmental diplomacy today depends on nations devising ways to manage resources in common such as the ocean, rainforests and the atmosphere. This diplomacy also depends on the ability of the more wealthy industrialized nations to cooperate with the poorer, less developed countries. This form of cooperation failed with seabed mining. But it must eventually succeed with more vital global resources. 
The idea for this thesis grew out of a conversation at a local pub that I had with Marie-Christine Aquarone and Rennie Lieber. I was not thrilled with an earlier thesis idea and realized I was more interested in the people who created this unusual field of Marine Affairs. Rennie noted that none of the required courses in the master's program seemed to delve into who these people were. I mentioned that $I$ was interested in writing a biography. Marie-Christine suggested I write a marine affairs biography. With the help and historical perspective of Lewis Alexander and some sound academic advice from Lawrence Juda, the project evolved into an intellectual history of an idea and its creators.

I would also like to thank Maury Klein who helped me approach the subject as a historian. His advice on biography also inspired me at various points when I needed it.

And I thank my friends in Vermont, where I lived for many years, and Rhode Island, my new home, who believed in me throughout this program and encouraged me to stick with it when I was wavering. I would especially like to thank Abbie Roses, Pauline Uchmanowicz, Susan Myette, Steve Rosenfeld and Kevin O'Connor. 
TABLE OF CONTENTS

INTRODUCTION 1

CHAPTER I

THE COMMON HERITAGE OF MANKIND IS INTRODUCED 9

CHAPTER II

THE ADVOCATES 36

CHAPTER III

THE MARRIAGE OF THE NEW INTERNATIONAL

ECONOMIC ORDER AND THE COMMON HERITAGE

OF MANKIND

63

CHAPTER IV

THE CONCEPT IS TRANSLATED INTO POLICY

73

CONCLUSION

104

APPENDIX

INTER VIEWS

BIBLIOGRAPHY

121 


\section{Introduction}

International political changes and oceanographic advances set the stage at the end of the 1960s for a rare flowering of idealism. Nurtured by this period of idealism, a little-known ambassador from Malta, Arvid Pardo, declared that the deep seabed should be considered the common heritage of mankind in 1967.1 The idea appealed to the world's developing countries and was turned into a United Nations resolution that the United States, other powerful developed countries and developing countries supported in 1970.2 The common heritage concept was expressed to the world again at the Third United Nations Conference on the Law of the Sea (UNCLOS). At this conference, representatives from 140 nations that did not include the United States agreed in 1982 that the deep seabed together with its resources should be considered the common heritage of mankind, a place to be managed by an international authority and to be mined for the enrichment of all nations, in particular the world's developing nations. But for a number of reasons, the concept could not be translated into workable international policy for the deep seabed.

Pardo drew upon an ancient belief that the ocean belonged to no man, no nation, but to all people of all nations when he shaped the common heritage concept. This belief was

1. United Nations, General Assembly, (Doc. A/C.1/PV. 1515, 1516), 1 November 1967.

2. United Nations, General Assembly, Res. 2749 (XXV), 17 December 1970. 
taken for granted when the ocean was a dangerous and remote place. But as technology began to remove the barriers to this no man's land, Pardo believed the chances increased that powerful maritime nations would take control of increasing amounts of ocean space and ocean wealth. It was this concern that set the stage for a new definition of the ocean as the common heritage of mankind. In 1970, the United Nations General Assembly passed a resolution at the urging of Pardo that defined the common heritage as: "the sea-bed and ocean floor, and the subsoil thereof, beyond the limits of national jurisdiction, as well as the resources of the area..."3

Technology, primarily improved equipment to extract oil from beneath the continental shelf and new instruments to examine the deep sea, provided the backdrop for the common heritage concept. However, scientists did not play as significant a role in developing policy for the deep seabed as political leaders. But the political leaders drew extensively of the writings of John Mero, a California engineer, who was one of the first to proclaim a great wealth of minerals in the seabed. 4 His ideas, which would later come under scrutiny and criticism, 5 were picked up by nonscientific world-stage players and used extensively to spearhead the common heritage concept in the 1970 s.

3. Ibid.

4. John Mero, The Mineral Resources of the Sea (Amsterdam: Elsevier, 1965).

5. Markus Schmidt, Common Heritage or Common Burden? (Oxford: Clarendon Press, 1989), p. 12. 
This thesis focuses on the individuals who articulated, defined and promoted the principle of the common heritage of mankind and applied it to the world's oceans. The motivations of these players varied. For some, the concept was a vehicle to achieve the so-called New International Economic Order6 by devising a way to include the emerging nations as managers of the ocean's deep seabed. It was the first significant test of this movement. 7 For others, the common heritage was an old idea that had not worked in other places, but might be successfully applied to a new place - the deep seabed. 8 For certain members of the nongovernmental organization movement, the common heritage was a way of achieving world federalism and a step toward world peace. 9 For others, it was a way of trying to distribute the wealth of the oceans in a more egalitarian manner. For some who were acting out roles assigned by their governments, it was a bargaining tool, a concept they might not have agreed to at any other time, but one that could be used as quid pro quo to get Third World nations to agree to other provisions of the 1982 United Nations Convention on the Law of the Sea. 10

6. P.N. Agarwala, The New International Economic Order: An Overview (New York: Pergamon Press, 1983).

7. Barbara Weaver, former activist with United Methodist Law of the Sea Project, personal interview with author, New York City, 20 September 1991.

8. Elisabeth Mann Borgese, et al., eds., The Tides of Change: Peace, Pollution and Potential of the Oceans (New York: Mason/Charter, 1975).

9. John Logue, ed., The Fate of the Oceans (Villanova: World Order Research Institute, 1972).

10. Claiborne Pell, "Introduction," San Diego Law Review, vol. 18, no. 3 (1981): p. 391. 
The hypothesis of this study is that the doctrine of the common heritage of mankind was a vehicle for many other goals - goals that were not always grounded in political, economic or technological reality. The political reality during the period when the idea was introduced was that there were enormous philosophical differences between some industrialized nations and the majority of developing countries on how much political power an international organization should have over what would be a business enterprise, mining the seabed for minerals. These differences made cooperation between countries with divergent philosophies difficult to negotiate. The doctrine was also touted at a time when industrialized nations feared a shortage of land-based minerals and feared they might be held captive by OPEC-like mineral cartels. ${ }^{11}$ These countries were looking for a new source of minerals that might be extracted from nuetral territory. However, the metal shortage abated by the 1980s when metal prices dropped worldwide, making seabed mining much less viable and an international mining venture less urgent. The concept was also based on an assumption that the technology to mine seabed minerals would become more accessible to developing countries in the near future. Time proved that this was unrealistic because seabed mining has not been done by developed or developing countries.

11. U.S. Congress, House, Committee on International Relations, Report of Congressional Research Service on Deep Seabed Minerals: Resources, Diplomacy, and Strategic Interest, 95th Cong., 2nd sess., 1 March 1978. 
The mining regime that developed at UNCLOS from the common heritage concept was not equipped to weather the rapidly changing nature of world politics or world economics. The regime included production controls and allowed for extensive control of private industry by the international organization. In the last two decades, criticism of government intervention in the market-place has grown. The fall of communism in Eastern Europe in the 1990s has caused policymakers to question the political viability of state-controlled economies. This general critique has helped to discredit the mining regime.

The people who first articulated the common heritage concept to the world, Arvid Pardo and Elisabeth Mann Borgese, who was to serve as an Austrian delegate to UNCLOS, envisioned a powerful international organization that would regulate oil drilling, mineral mining, scientific research, military use and environmental protection of an area of ocean space that would begin just beyond the territorial sea. The resulting 1982 United Nations Convention on the Law of the Sea seabed provisions did not create such a broad and powerful entity. The treaty created a regime for mining seabed manganese nodules in an area beyond the newly created Exclusive Economic Zone. ${ }^{12}$ The United States and some other industrialized nations rejected the entire seabed portion of the

12. The exclusive economic zone is an area beyond the territorial sea which extends 200 miles beyond the baseline of a nation. It is defined in Part $\mathrm{V}$ of the 1982 United Nations Convention on the Law of the Sea, reprinted in International Legal Materials, vol. XXI, no. 6, (November 1982): p. 1279. 
treaty and have yet to sign the convention. This has left international marine policy with an unsuccessful doctrine.

A major goal of the thesis is to set a precedent by writing an intellectual history that identifies the thinkers who developed, articulated, shaped and promoted a significant doctrine of modern ocean law. The thesis also examines that moment in history when marine policy coalesced around the common heritage concept. Heightened understanding of this moment and the thinkers and ideas that helped create it could assist future leaders in marine affairs to form new ideas and translate them into policy. The evolution of the common heritage concept and its failure to create viable economic policy might also provide policy-makers with some warnings of possible pitfalls.

Yet, this thesis does not conclude the common heritage was a complete failure. Although the concept has not yet resulted in seabed mining that contributes wealth to the world's poorer nations, it does promote worldwide acceptance that the deep seabed belongs to all people and is not to be carved up among nations. The extensive discussion of creating a new international law infused the emerging field of marine affairs with excitement and energy.

This study is significant because few writers have examined the people behind the ideas that form the foundation of marine affairs. ${ }^{13}$ Yet in other fields, the thinkers become

13. Biographies have been written about Hugo Grotius, one of the founding fathers of international ocean law. See Edward Dumbauld, The Life and Legal Writings of Hugo Grotius (Norman, Oklahoma: University of Oklahoma Press, 1969). 
well known not only to those in the field but to the outside world. The public has learned about the fields of science, law, philosophy and history by examining inspirational leaders, their motivations and their choices. The author hopes that applying this same approach to a selected marine affairs doctrine will assist not only the academic community, but the general public to better understand the evolution of marine affairs.

Some of the questions that are posed in this thesis are: Who are the primary thinkers who created and shaped the common heritage concept and what were their motivations? What were the strengths and weaknesses of the approaches taken by the people who promoted the idea? How broadly based were their constituencies? To what extent did the principle of the common heritage of mankind gain international acceptance as seen in United Nations resolutions and the 1982 Convention on the Law of the Sea? What might be the long term effect of the doctrine?

The first chapter of this study is an examination of Ambassador Arvid Pardo's introduction of the concept of the common heritage of mankind in 1967. The chapter delves into some of the predecessors to Pardo's idea and explains the historical context in which Pardo defined the concept. It presents some background on Pardo and examines his motivations. The second chapter introduces some of the 
advocates of the common heritage concept. Some of the strongest advocates were individual people who had worked for the causes of international peace and social justice. This chapter pays particular attention to the role that Elisabeth Mann Borgese, a German-born internationalist, played promoting Pardo's ideas and building an international constituency for a broad array of marine issues. The chapter also examines some of the fledgling United States nongovernmental groups that promoted the concept. The third chapter examines the marriage of the common heritage concept with the Third World aspirations for what was called a New International Economic Order. The fourth chapter is an analysis of what became of Pardo's idea for a common heritage regime for the oceans. The analysis looks at the policy that emerged in the 1982 United Nations Convention on the Law of the Sea, the preparatory commission work after the treaty negotiations and the United States increasing disenchantment with the concept. The final chapter is a conclusion and evaluation of the common heritage of mankind concept. 
Chapter I - The Common Heritage of Mankind is Introduced.

Arvid Pardo, the ambassador from the tiny island country of Malta, submitted a proposal to the United Nations on August 17, 1967 that would contribute to a major change in global thinking. Ambassador Pardo said years later that he was motivated by a dream in 1967 when he proposed the General Assembly include on its agenda a "Declaration and Treaty concerning the reservation exclusively for peaceful purposes of the sea-bed and of the ocean floor, underlying the seas beyond the limits of present national jurisdiction, and the use of their resources in the interests of mankind."1 Pardo was also motivated by a deep desire to encourage a new style of international relations that would revamp the pattern of economic, political and geographic control by wealthy, industrialized nations. ${ }^{2}$ In a three-hour speech at the United Nations on November 1, 1967, Pardo gave the world a first glimpse of his idea that the deep seabed and its resources should be considered the "common heritage of mankind."

Pardo linked the common heritage idea to the history of ocean law. He suggested that the world had reached a new era in ocean use that demanded a novel legal concept to govern the

1: Arvid Pardo, telephone interview with author, 2 December 1991 and Note verbale from U.N. (Doc. A/6695), 17 August 1967.

2. ibid., Note verbale. 
previously ignored area of the deep seabed. ${ }^{3}$ His idea took hold in the late 1960s largely because it combined a number of international concerns including the ocean environment, disarmament, the future of lesser-developed countries and a critique of liberal capitalism. Global attention was turning toward the ocean as one of the last areas on earth that had not been claimed, explored or exploited. It was also a time when the United States and the Soviet Union were engaged in a scientific race to explore outer space. Leaders of smaller countries that had more at stake in the ocean than in outer space did not want to see the two global powers fight for control of the oceans and their resources. The danger that such a competition posed was not just that one side would lose resources to the other, but also of war on the planet.

Pardo's idea also took hold because he was echoing some earlier suggestions of what should be done with the ocean's deep seabed and its resources. The precursors to Pardo's idea can be traced to ancient Roman Law.

The Institutes of Justinian, the body of Roman law, states that under the Law of Nature "these things are common to mankind - the air, running water, the sea and consequently the shores of the sea." 4 In Roman law these common areas were considered res nullius or res communis. Res nullius referred to something which while not owned could eventually be owned by someone. International law developed so that there were

3. U.N. (Doc. A/C.1/PV. 1515, 1516), 1 November 1967.

4. Thomas C. Sandars, ed., The Institutes of Justinian (Westport, CT: Greenwood Press, 1922), p. 90 
various ways for countries to claim property said to be res nullius. ${ }^{5}$ However, if an area was considered res communis, it was owned by the community of mankind and therefore could not be claimed. Pardo drew from these ancient concepts when he fashioned his concept of the common heritage of mankind. His concept, as will be explained, resembled the res communis.

Technology for offshore oil drilling and improved oceanographic research thrust the seabed into the international legal arena in 1958 at the First Conference on the Law of the Sea. Prince Wan Waithayakon of Thailand stated at that conference that the "sea is the common heritage of mankind." 6 However, the conference did not establish a legal regime for the seabed. It was not yet a compelling issue; the use of the seabed was still in the realm of science fiction for most people.

During the 1950 s and the 1960 s, some people began suggesting that the United Nations be given jurisdiction over the seabed. The Commission to Study the Organization of Peace, an American group, urged in 1957 that the United Nations General Assembly "declare the title of the international community" to the deep seabed and establish administrative arrangements. Clark Eichelberger, a member of the commission, a proponent of United Nations jurisdiction,

5. Henry Black, Black's Law Dictionary ,5th Edition (St. Paul, Minn.: West Publishing Co., 1979), p. 1174.

6. Cited in Bernardo Zuleta, "Introduction," San Diego Law Review, vol. 17 (1980):

p. 524 . 
suggested it was a way of providing the international body with its first independent source of money. ${ }^{7}$

Pardo's speech also echoed an idea that had at least been hinted at in American marine policy. Although he spoke in nowhere near the detail as Pardo, President Lyndon B. Johnson alluded to the concept of a common heritage on the seabed in 1966 when he commissioned the USS Oceanographer and issued a report on the ocean composed by the President's Science Advisory Committee.8 The Johnson speech and the report entitled, Effective Use of the Sea, ${ }^{9}$ signaled that United States policy-makers were ready to address the seabed. Johnson's speech at the commissioning of the research vessel also demonstrated optimism about ocean policy. The 1960s were the American heydey in ocean policy. 10 The ocean was high on the national agenda for a combination of reasons including a rebirth in science education fueled by the space race between the Soviets and the Americans, specific ocean technology advances, the beginnings of an environmental movement stessing land and water protection and a search by the United States for ways of creating international bonds

7. U.S. Congress, Senate, Committee on Foreign Affairs, Subcommittee on Ocean Space, Hearings on Activities of Nations in Ocean Space, 91st Cong., 1st sess., 24 July 1969 , p. 150.

8. Public Papers of the President, Lyndon B. Johnson, 1966, Book II, p. 722.

9. Effective Use of the Sea, Report of the Panel on Oceanography of the President's Science Advisory Committee (Washington, D.C.: U.S. Government Printing Office, June 1966).

10. Lauriston R. King and Feenan D. Jennings, "The Executive and the Oceans: Three Decades of United States Marine Policy," Marine Technology Society Journal, vol. 22 , no. 1 (1988): p. 17-32. 
through programs such as the Peace Corps, Food for Peace and the U.S. Administration for International Development. The tone of the era was set by the grandiose idealism of Johnson's Great Society programs. The language President Johnson used in his July 13, 1966 dedication of the Oceanographer gives a flavor of the attitude toward the ocean at the time.

"We meet here today at the beginning of a new age of exploration," Johnson told a gathering at Pier 2 in the Washington Navy Yard. "To some this might mean our adventures in outer space. But I am speaking of exploring an unknown world at our doorstep. It is really our last frontier here on earth. I am speaking of the mountain chains that are yet to be discovered, of natural resources that are yet to be tapped, of a vast wilderness that is yet to be charted.

This is the sea around us." 11

Not only does the speech's rhetoric tap into the American myth of the frontier, but it also alludes to the best-selling book on the ocean published by Rachel Carson in 1951.12 In the speech, Johnson explained that the Oceanographer, one of the Coast and Geodetic Survey's fourteen research ships, would improve the country's understanding of the ocean. He said federal support for marine science was on the rise from an estimated $\$ 21$ million in 1950 to $\$ 320$ million in 1960 . He stressed the need for cooperation especially between the Soviet Union and the United States in scientific research and he

11. Public Papers, LBJ, p. 722.

12. Rachel Carson, The Sea Around Us (New York: Oxford University Press, 1951). 
announced that the nation would invite other countries to participate in a round-the-world voyage of the Oceanographer. In the closing sentences of his speech, Johnson called the ocean floor a "legacy to all humans."

We greatly welcome this type of international participation. Because under no circumstances, we believe, must we ever allow the prospects of rich harvests and mineral wealth to create a new form of colonial competition among the maritime nations. We must be careful to avoid a race to grab and to hold the lands under the high seas. We must ensure that the deep seas and the ocean bottoms are, and remain, the legacy of all human beings. 13

On the same day that Johnson delivered this speech, he also issued Effective Use of the Sea. The report was the result of a year of study and work by the President's Science Advisory Committee, a group composed predominantly of academics. It appeared just as Congress was enacting the Marine Resources and Engineering Development Act. Both the report and the act concluded that the United States lacked an adequate program to "explore, understand and develop the oceans." 14 The report detailed a history of American ignorance of the vast oceans at its western and eastern doorsteps. It echoed some of the conclusions of a 1959 report by a National Academy of Science Committee on Oceanography which said the United States was uncompetitive and not in an international leadership position in oceanography. Effective Use

13. Public Papers, LBJ, 722.

14. Effective Use of the Sea, p. vii. 
of the Sea recommended establishing a new agency to oversee ocean and atmosphere issues. The phrase, common heritage of mankind, was not used in Effective Use of the Sea, however, the report urged "cooperative, international efforts to develop marine resources for the benefit of humanity." And it urged the United States to assert itself quickly or risk losing a voice in an emerging new order for the oceans. ${ }^{15}$

During the summer of 1966, Congress also enacted the Great Society's program for the ocean, called the Marine Resources and Engineering Development Act. ${ }^{16}$ This act created the Commission on Marine Science, Engineering and Resources, a 15-member president-appointed body to identify national objectives for ocean research, environmental protection and fish and resource development. The commission, headed by Julius Stratton, was made up of appointees drawn from government, industry, universities and laboratories. It issued a report, called the Stratton Report, in 1969, calling for major national ocean technology improvements, a federal-state coastal zone management program, improved use and management of national and international fisheries and greater national attention to the formation of international cooperatives to use and protect the deep oceans.

The Johnson speech and the Stratton Commission's beginnings were in the background when Pardo made his

15. Ibid., p. 3.

16. Our Nation and The Sea: A Plan for National Action, Report of the Commission on Marine Science, Engineering and Resources (Washington: U.S. Government Printing Office, 1969). 
speech. Also, the World Peace Through Law Center, an organization representing more than 200 lawyers from 100 countries, resolved in July 1967 that there should be an international regime to manage the deep seabed. New York lawyer Aaron L. Danzig organized the meeting of the United Nations Committee of the World Peace Through Law Center which recommended to its parent organization that the high seas and all its fish and mineral resources be subject to U.N. jurisdiction. The parent body, however, limited the recommendation to non-fishery resources of the high seas. The organization resolved:

Whereas, new technology and oceanography have revealed the possibility of exploitation of untold resources of the high seas and the bed thereof beyond the continental shelf and more than half of mankind finds itself underprivileged, underfed and underdeveloped, and the high seas are the common heritage of all mankind.17

Pardo disagreed with the idea of placing the United Nations in charge of this vast territory and made this clear in his speech. In this way, he deviated from a number of thinkers. Calling United Nations oversight impractical, Pardo thought it "hardly likely that those countries that have already developed a technical capability to exploit the seabed would agree to an international regime if it were administered by a body where small countries, such as mine, had the same voting power as

17. Lewis Alexander, ed., International Rules and Organization for the Sea:

Proceedings of the Third Annual Conference of the Law of the Sea Institute, June 24-27, 1968 (Kingston, RI: The University of Rhode Island, 1968), p. 375. 
the United States or the Soviet Union." 18 He suggested that industrialized countries should have more to say about managing the seabed than the lesser developed countries. Pardo also laid out in clear language (1) the reasons for a new concept in ocean management, (2) the danger in not creating a new legal concept for governing the oceans (3) the specific advantages of exploiting the seabed and (4) a general design for a regime to govern the ocean as a common heritage of mankind.

Pardo noted in his speech that the nations of the world had accepted the concept of freedom of the seas as defined by Hugo Grotius in the seventeenth century. ${ }^{19}$ This concept covered the uses of the water component of the seas, but Pardo believed it did not address the seabed beyond the limits of national jurisdiction.

Around the use of the surface and upper layers of the seas a complex body of international law has developed; but the depths of the oceans and the ocean floor were of little interest until little more than a hundred years ago when the question of laying transatlantic cable came to the fore. 20

Pardo also stressed the need for a new legal concept because he believed the 1958 United Nations Conference on the Law of the Sea Convention on the Continental Shelf had left ambiguity in the definition of the continental shelf. $\mathrm{He}$

18. U.N. (Doc. A/C.1/PV.1516), 1 November 1967.

19. Gerhard von Glahn, Law Among Nations, 5th Edition (London: Macmillan

Publishing Co., 1986), p. 31.

20. U.N. ( Doc. A/C.1/PV.1515), 1 November 1967. 
maintained the treaty's definition gave nations freedom to broadly interpret how far the continental shelf extended and thus the extent of a nation's right to exploit the resources of the shelf. National territory at the time Pardo gave his speech extended for many, but not all nations, to a three-mile territorial sea. Beyond this, the 1958 treaty gave a nation rights to exploit the natural resources of the continental shelf, but did not grant sovereignty over the shelf to coastal states. ${ }^{21}$ Pardo referred to the following section of the 1958 convention when he argued that it left a dangerous ambiguity and left room for international disputes over where a nation's shelf ended and the seabed began.

...the term continental shelf is used as referring (a) to the seabed and subsoil of the submarine areas adjacent to the coast but outside the area of the territorial sea, to a depth of 200 metres or, beyond the limit, to where the depth of the superjacent waters admits of the exploitation of the natural resources of the said areas...22

Under such a definition, technology. and the ability to exploit would define where the shelf ended and the seabed began. Obviously it gave clear advantages to nations with superior technology and Pardo was worried it might encourage these nations to make claims to the deep seabed area.

Pardo urged that a new legal framework for the vast ocean seabed should be established before governments used

21. 1958 United Nations Conference on the Law of the Sea, Convention on the Continental Shelf, Art. 2, 29 April 1958, Treaties and Other International Acts Series 5578 .

22. Ibid. Art. 1. 
current international law to justify occupation, military buildup, nuclear weapons installation or commercial exploitation of the seabed. He wanted to devise a new concept for the ocean that differed from the legal concept of res nullius which formed the philosophical foundation for the concept of freedom of the seas. Under the concept of res nullius, there are parts of the globe that are owned by no one. But internationally accepted legal methods exist to gain sovereignty over these areas. The primary method is through discovery and occupation. 23 The concept of res nullius ushered in the age of exploration and allowed Europeans to claim continents and colonize peoples who did not have the same form of written, international law.

Pardo's idea of the common heritage of mankind more closely resembled the Roman legal concept called "res communis." Under the concept of res communis, an area may not be appropriated and the use of it belongs equally to all people. 24 This is the philosophical underpinning of the common heritage concept. However, Pardo and other scholars have pointed out that the common heritage concept went beyond res communis because it included "the actual sharing of the benefits" derived from an area or resource. 25 Pardo said in a statement made on March 20, 1969 that there was a distinction between res communis and the common heritage of

23. von Glahn, Law Among Nations, p. 315-327.

24. Milan Bulajic, Principles of International Development Law (Boston: Martinus Nijhoff Publishers, 1986), p. 305.

25. Ibid., p. 305-306. 
mankind. He defined res communis as an area "usable for any convenient purpose." He said that the resources in such an area are indiscriminately and competitively exploitable. However, he said the common heritage area had a "special status" because it would be reserved exclusively for peaceful purposes and would be "administered by an international agency in the name and for the benefit of all peoples and of present and future generations." 26 Pardo observed that the existing international law would allow powerful nations to claim the deep seabed and its mineral resources in the same way that the European nations had carved Africa into colonies in the nineteenth century.

Unfortunately the present juridical framework clearly encourages, subject to certain limitations, the appropriation for national purposes of the sea-bed beyond the geophysical continental shelf. As I have already had occasion to mention, the sea-bed and the ocean floor are land. There are five generally recognized modes of acquiring land in international law: cession, subjugation, accretion, prescription and occupation. 27

In this statement, Pardo criticized the international law that allowed nations to acquire land. Cession is the "formal transfer of title from one state to another. ${ }^{28}$ Subjugation is the "firm military conquest" of a people and their territory. 29 Roman law defined accretion as the gradual deposit of soil by a

26. Arvid Pardo, The Common Heritage: Selected Papers on Oceans and World Order 1967-1974 (Malta: Malta University Press, 1975), p. 67.

27. U.N. (Doc. A/C.1/PV. 1515), 1 November 1967.

28. von Glahn, Law Among Nations, p. 318.

29. Ibid., p. 638. 
river or ocean along the shore. The law gave the owner of the river bank or shore the right to the newly accreted land.30 Prescription means that a "foreign state occupies a portion of territory claimed by another state, encounters no protests by the owner, and exercises rights of sovereignty."31 Occupation is a situation in which a nation takes over, occupies territory and eventually owns the land.

Pardo urged that no one be allowed under old rules of international law to own the seabed. He wanted to introduce a concept in international law that promoted equality and social welfare for poorer nations in current and future generations. 32 This was a significant departure from international law concerned with traditional security issues. Pardo's concept of the common heritage was part of a larger trend in international relations that would continue into the 1970s. Welfare issues such as sharing resources emerged at this time because it was possible to pay less attention to security issues. The East-West detente gave nations a chance to shift focus toward issues such as the ocean and the environment. 33

To stress his belief in the need for new law and the danger of inaction, Pardo said that the United States had already begun leasing tracts of underwater land well beyond

30. Ibid., p. 316.

31. Ibid., p. 317.

32. For more information on the shift in international legal philosophy from traditional security to human welfare concerns see Julius Stone, Visions of World Order: Between State Power and Human Justice (Baltimore: The Johns Hopkins University Press, 1984).

33. Donald J. Puchala and Stuart I. Fagan, "International Politics in the 1970s: the Search for a Perspective," International Organization, vol. 28, no. 2 (1974): p. 2 
territorial waters. He warned that this trend would continue unless an international body established a new legal regime to protect the deep seabed from creeping national claims.

The process has already started and will lead to a competitive scramble for sovereign rights over the land underlying the world's seas and oceans, surpassing in magnitude and in its implication last century's colonial scramble for territory in Asia and Africa. The consequences will be very grave: at the very least a dramatic escalation of the arms race and sharply increasing world tensions, caused also by the intolerable injustice that would reserve the plurality of the world's resources for the exclusive benefit of less than a handful of nations. The strong will get stronger, the rich richer and among the rich themselves there would arise an increasing and insuperable differentiation between two or three and the remainder. Between the very few dominant Powers, suspicions and tensions would reach unprecedented levels. Traditional activities of the high seas would be curtailed. ${ }^{34}$

One weakness of Pardo's speech was that he cited only one source - Mineral Resources of the Sea, by the American engineer, John Mero, when estimating the specific economic advantages of seabed mining.

In his book Mr. Mero states that manganese nodules could be mined, transported to port and processed at a cost of some $\$ 28.5$ per ton, as compared to gross commercial value of recoverable metal content ranging from $\$ 40$ to $\$ 100$ per ton. ${ }^{35}$

34. U.N. (Doc. A/C.1/PV.1515), 1 Novemer 1967.

35. Ibid. 
The press release issued by the United Nations to newspapers noted that Pardo's estimated $\$ 5$ billion could be raised by 1975 from seabed mining.36 This figure was Pardo's extrapolation of Mero's estimates.This was a weak part of the speech because the knowledge about the seabed and its resources was in its infancy. Within a few years, Pardo's predictions would seem ridiculously optimistic.

In the final section of his speech, Pardo delineated for the first time the components of the common heritage concept as applied to the deep seabed. First, it was a concept that provided for exploitation of a natural area to benefit all mankind. Second, the area was to be used exclusively for peaceful purposes. Third, the international community was to have jurisdiction, but not sovereignty over the common heritage of mankind area and resources. An agency that represents the international community would act as a "trustee for all countries over the oceans and the ocean floor to regulate, supervise and control all activities on or under the oceans and the ocean floor," Pardo said. ${ }^{37}$ The concept would promote exploitation of resources in the interests of mankind, with particular regard for the needs of poor countries and scientific research to be conducted freely by all with the results shared by all.

36. Sam Pope Brewer, "Malta Warns UN on Radioactive Pollution at Sea," New York Times, 2 November 1967, p. 12.

37. U.N. (Doc. A/C.1/PV.1515), 1 November 1967. 
Nearly twenty years later, Christopher C. Joyner defined the concept of the common heritage of mankind in nearly identical fashion, a testament to the lasting power of Pardo's original definition. Joyner described five principle elements to the concept of the common heritage of mankind. They are that (1) common space areas would legally be owned by no one, (2) all people would be expected to share in the management of a common space area, (3) economic benefits from natural resources exploited from the common space would be shared internationally, (4) use of the common space area would be limited to peaceful purposes and (5) scientific research would be conducted freely and openly and not threaten the environment. The results should be "freely and publicly exchanged in hopes of fostering greater scientific co-operation and more extensive knowledge of the region." 38 The major differences between the views of Pardo and Joyner was Pardo's insistence that the common heritage of mankind be used primarily for the poor of the world. Joyner gave no preference to any social group, but he did reflect a greater awareness of the need to protect the environment.

These differences can be attributed to the different decades. The 1960 s were a period when leaders talked about social responsibility. This was reflected in Pardo's desire to use the fruits of the sea to raise the living standards of the poor in developing countries. The late 1960s was a period of

38. Christopher C. Joyner, "Legal Implications of the Concept of the Common Heritage of Mankind," International and Comparative Law Quarterly, vol. 35 (1986): p. 191-192. 
international idealism. In America, President Lyndon Johnson had launched the War on Poverty and Martin Luther King Jr. was leading a civil rights movement to raise the political, economic and social possibilities for black people. Africans were struggling in newly created countries to establish governments and devise ways to feed, educate and employ starving masses. Pardo's speech came at a time when the size and character of the United Nations was also changing each year. For example in 1966, the United Nations membership was 121 nations, almost three times the original founding membership of 1945.39

At this time, America was engaged in a bloody and controversial conflict in Vietnam, but President Johnson was also concerned about promoting international peace whether it was through international aid programs or ocean development ideas. In 1966, Johnson urged Congress to approve $\$ 3.3$ billion a year in aid for a new program he called Food For Freedom to assist the nations - predominantly in Africa - where people were starving. 40 That same year, Johnson gave his speech identifying the ocean as a new arena for international cooperation.

The 1960s were also a time when capitalism was criticized by a number of world leaders. On March 28, 1967, Pope Paul VI issued a papal encyclical entitled "On the Development of Peoples" in which he urged "unselfish

39. Luman H. Long, ed., The World Almanac 1967 (New York: Newspaper Enterprise Association, 1966), p. 678.

40. Ibid., p. 678. 
nonpolitical action for economic and social justice." He condemned what he called the "evils of unrestrained capitalism." 41 He said the right of property should be subordinate to the common good.

This was the 1960s. The 1980s, on the other hand, were not known for altruism on national or world levels. The global economy had deteriorated. The economically powerful Asian countries of Japan, Korea and Taiwan were beginning to displace the western powers. National leaders like Ronald Reagan and Margaret Thatcher were preaching an antigovernment, pro-private enterprise philosophy. A philosophy that was nearly the opposite of the international idealism of the late 1960 s common heritage concept. However, by the 1980s, the environment was firmly on the agenda of international relations. It was recognized as linked to global political stability.

Pardo's speech suggested that the international regime should (1) oversee commercial mining 2) assure that the area be used only for peaceful purposes and 3) be responsible for curbing ocean pollution. He stressed that international management would promote peace and security: international mining for oil, gas and other minerals would free the world community of dependence on more politically sensitive land sources. He also stressed this as a reason for the technologically-advanced countries to favor an international

41. Robert C. Doty, "Pope Paul Calls for Urgent Steps to Aid Poor Lands," New York Times, 29 March 1967, p. 1. 
regime. These countries depended on some of the lesser developed countries in Africa and Latin America for raw materials such as oil and minerals. ${ }^{42}$ He claimed an international regime for the deep sea could prevent international conflict over valuable resources.

As will be seen, Pardo's background as an internationalist influenced his decision to champion the principle of the common heritage of mankind. His position as ambassador from Malta, a 122 square-mile nation in the Mediterranean, also assisted him in the promotion of the idea. Malta fell on neither side of the North-South debate or of the Cold War division between the Soviet bloc countries and the United States. This gave Pardo credibility through neutrality.

The idea also was a way for Pardo to combine some of his previous work at the United Nations on disarmament issues, UN reorganization ideas and Third World development concerns. Pardo joined the United Nations staff in September 1946, one year after he was freed from a German concentration camp in Berlin. During the Second World War, he founded an underground movement in Italy to aid the Allies. He was imprisoned by the Mussolini government in 1940 and spent two years in solitary confinement at the Regina Coeli prison in Rome. In October, 1943, he was deported to Germany and put

42. U.S. Congress, House, Committee on International Relations, Report of the Congressional Research Service on Deep Seabed Minerals: Resources, Diplomacy and Strategic Interest, 95th Cong., 2nd sess., 1 March 1978, p. 60. 
in the concentration camp at Grossbeeren and later moved to the Alexander Platz prison in Berlin. ${ }^{43}$

He served as acting chief of archives at the UN, worked for the division of "Non-Self-Governing territories," was the representative of the U.N. Development Program in Nigeria from 1961-63 and Ecuador from 1963-64. When Malta gained its independence from the United Kingdom in 1964, the new Maltese prime minister, Giorgio Borg Olivier, asked Pardo, a personal friend, to serve as the nation's first ambassador to the United Nations.44 A year before his famous speech in 1967, Pardo introduced a resolution to control the trade of weapons.45 Pardo served as the Maltese ambassador until 1970 when a new government took over Malta. He then worked as a civil servant at the United Nations and later sought a professorship in the United States. He was a professor of international relations and senior research fellow at the University of Southern California. He is currently retired in Texas. Before his UN work, Pardo had received a degree in history from the University of Tours and a doctorate in international law from the University of Rome.

This background helps explain why Pardo's concept for the deep seabed was his idea and not part of Malta's national agenda. "I had to be careful. The idea was never cleared with the voters of Malta," Pardo said. "I was not eager to develop the

\footnotetext{
43. Pardo, Common Heritage, p. i.

44. Arvid Pardo, telephone interview with author, 2 December 1991.

45. Pardo, Common Heritage, p. v.
} 
full implications of the common heritage of mankind in an explicit manner." 46

Pardo chose to champion an international regime for the deep seabed because he viewed this remote region of the world as a safe place to shape a new form of international cooperation. 47 He had no experience with mineral mining. He was not an oceanographer although he had a layman's interest in the technological advances that were opening up man's knowledge of the deep ocean and demanding, in his opinion, an international management regime.

"I had nowhere else to go," said Pardo when he described why he chose to suggest the common heritage of mankind concept be applied to the deep seabed. "If I had said ocean space, the matter never would have been accepted. The seabed was the only place on earth that did not have the beginnings of a legal structure. 48

Pardo elaborated on his idea of a new international organization that he thought would work better than the United Nations in his 1971 draft international ocean space treaty. His and other proposed treaties were presented to the United Nations Sea-bed Committee, a body set up in 1968 by the United Nations General Assembly to study the uses and management of the seabed. $49 \mathrm{He}$. wanted to give certain

\footnotetext{
46. Arvid Pardo, telephone interview with author, 2 December 1991.

47. Ibid.

48. Ibid.

49. Shigeru Oda, ed., The International Law of the Ocean Development (Leyden:

Sijthoff International Publishing Co., 1972), p. 148.
} 
privileges and rights to the countries most affected by the marine environment. To do this he suggested the seabed regime have an assembly made up of representatives from each nation. However, these members would be broken down into three categories: coastal states with a population exceeding 90 million, all remaining coastal states and non-coastal states. Decisions made by the assembly would be taken by an affirmative vote of the majority and by a majority of members belonging to two of these three sub-categories. 50

Pardo thought the United Nations General Assembly system was unwieldy and believed a new system that gave appropriate weight to nations with concerns about the marine environment would be fairer and effective. However, his design was not that different from the United Nations General Assembly where each nation has one vote. What was different was that there was no Security Council, a body that gives veto power to a select group of historically powerful nations. Instead, power was distributed based on ocean reliance and population.

Despite President Johnson's speech about the ocean and other proposals to internationalize management of the deep seabed, the United States was caught off guard by Pardo's common heritage concept. Congress reacted unfavorably beginning in the fall of 1967 when word spread about Malta's August 17 th note verbale suggesting a seabed regime. House

50. Oda, International Law of the Ocean Development, p. 174-5 
members introduced 22 resolutions specifically opposing "vesting title to the ocean floor in the United Nations." 51

The House Committee on Foreign Affairs, Subcommittee on International Organizations reviewed the resolutions and concluded that it would be premature and unwise to vest jurisdiction over the seabed in a new international organization. The subcommittee recommended the United States actively discourage any action that might "prejudice national interests in exploration, use and economic exploitation"52 of the seabed. During a month of hearings on the resolutions, the subcommittee heard from Ronald Reagan, who was governor of California at the time, that he was strongly against an international regime for the deep ocean. President George Bush, a member of the House from Texas at the time, also authored a resolution against vesting title to the seabed in an international organization. 53 Amid the flood of opposition there was one resolution in favor of encouraging the United Nations to develop a regime for the deep seabed that would provide a source of revenue for poor nations and the

51. Quoted from House Joint Resolution 816, 90th Cong., 1st sess. This resolution and 21 similarly worded resolutions were the subject of hearings by the House Committee on Foreign Affairs, Subcommittee on International Organizations from 22 September to 31 October 1967. For testimony and descriptions of House Joint Resolutions 816-824, 828-829, 834-837, 840,843-844,850,856,865, 876 and 916 see House Report No. 999, Interim Report on The United Nations and the Issue of the Deep Ocean Resources, 90th Cong. 1st sess., 7 December 1967.

52. Ibid., p. $4 R-5 R$.

53. See copy of telegram from Gov. Reagan to Rep. Dante B. Fascell of Florida, chairman of the Subcommittee on International Organizations, reprinted in House Report No. 999, p. 33. For Rep. Bush-sponsored resolution see p. 77. 
United Nations. House Resolution 558 was sponsored by Rep. Jonathan B. Bingham of New York. 54

The infant American mineral extraction industry turned to Congress in the late 1960 s with concerns that Pardo had proposed a socialistic international regime that would control and thwart their efforts to begin deep seabed mining. 55 Congress wanted to protect the mineral extraction industry's rights of access to the seabed. Sen. Lee Metcalf, the chairman of the Senate Interior and Insular Affairs Committee, Subcommittee on Minerals, Materials and Fuels, asked the American Mining Congress to draft national legislation that would protect seabed miners. 56

However, within the Senate, Sen. Claiborne Pell, a Democrat from Rhode Island, embraced some of the components of Pardo's idea. In the same month as the speech, Pell sponsored two resolutions, one which favored an international regime and the other which lay down a set of "basic principles for governing the seabed" to be recommended to the United Nations General Assembly. 57 Pell's Senate Resolution 186 laid down a "Declaration of Legal Principles Governing Activities of States in the Exploration and Exploitation of Ocean Space" which differed from Pardo's idea because it trumpeted the age old concept of freedom of the

54. Ibid., p. 77.

55. Ann L. Hollick and Robert E. Osgood, New Era of Ocean Politics (Baltimore: The Johns Hopkins University Press, 1974), p. 22.

56. Ibid., p. 58.

57. U.S. Congress, Senate, Committee on Foreign Relations, Hearing on Governing

the Use of Ocean Space, 90th Cong., 1st sess., 29 November 1967. 
seas and did not suggest that be replaced. "All states have the right for their nationals to engage in fishing, aquaculture and in-solution mining in the high seas beyond 12 miles from the coast...," the Pell principles said.58 Unlike Pardo, Pell recommended an appropriate authority designated by the United Nations issue licenses to nations for the exploitation of seabed nonliving resources and living resources that are "sedentary species." Pardo had suggested an independent international regime have broad powers to manage the resources of the deep sea. He wanted a separate government as if this region of the ocean would be a new country.

Pell's suggestion arose from the American philosophy of minimizing regulation. The primary goal of the proposal was to allow for orderly and efficient exploitation of the seabed. It did not aim to create a new source of money to feed the hungry or promote development in the world's poorer nations. Pell wanted to ensure world order and protect international security. However, he agreed with Pardo's idea of decreeing the seabed and subsoil be used for peaceful purposes and be protected from environmental harm. Pell does not mention the "common heritage of mankind," however his declaration states that there is a "common interest of all mankind in the progress of the exploration of ocean space and the exploitation of the resources in ocean space for peaceful purposes."59 The principles encouraged international cooperation in science, but

58. Ibid, p. 4.

59. Ibid., p. 3. 
did not take the step that Pardo had taken of saying that scientific information compiled by one country on the deep seabed should be the property of all countries.

Pell said that if the principles were followed, they would give "the edge to those nations who now are most technologically advanced and thus most able to take advantage of the resources."60 Pell and the Assistant Secretary of State, Joseph Sisco, had difficulty with Pardo's idea that lesser developed countries should be given preferential treatment in the use of resources from this new territory - the deep seabed. 61

Pardo had begun the process of changing international marine policy by identifying and defining the concept of the common heritage and how it should be applied to the deep ocean seabed. It was clear from the start and would become clearer that he took a philosophical approach and not a traditional legal approach. The idea and the approach might have gone completely unnoticed in 1967 had not a number of other forces helped to bring it to the fore. Among those forces were the discussions in the United States of a need to better understand and use the oceans. Like Pardo, key United States policy-makers including President Johnson and Vice President Hubert H. Humphrey 62 considered the ocean a vehicle for a

60. Ibid, p. 13.

61. Ibid., p. 21.

62. See letter from Humphrey to Senate Committee on Foreign Relations, Subcommittee on Ocean Space, Hearings on Activities of Nations in Ocean Space, 91st Cong., 1st sess., 24, 25, 28 and 30 July 1969, p. 249. 
number of goals, not just improved use of ocean resources such as fish or minerals. The president's science advisory commission report Effective Use of the Sea stressed the ambitious idea that Americans should apply their knowledge from land development to the ocean and should use the ocean to foster international cooperation in both exploration and exploitation. The report also stressed the security risks presented by this massive unclaimed area. It encouraged the United States to increase its presence in the ocean in order to prevent future security threats. Sen. Pell also advocated that the United States take a leadership role in the debate over how the deep sea should be governed. He saw that other countries were getting involved in this debate and feared the United States would lose ground if it did not jump into the fray with positive proposals of its own. 


\section{Chapter II - The Advocates}

The idea of the deep seabed as a common heritage of mankind attracted a fervent following among a small group of private citizens who formed fledgling nongovernmental organizations. NGOs, as they are now called, were not new to international politics, however, they were gaining importance in the 1970s. ${ }^{1}$ The motivations of some of the NGOs that took up the cause of the common heritage of mankind varied as did the way each defined the concept. As with Pardo and political figures from the United States, each NGO leader brought a different set of desires to the concept and tried to use the common heritage of mankind as a vehicle to achieve his or her goals.

Elizabeth Mann Borgese was a researcher at the Center for the Study of Democratic Institutions in Santa Barbara, California in 1967 when she read about Arvid Pardo's United Nations speech on the common heritage of mankind. At the time, she was reviving her interests in international relations and Pardo's speech reminded her of work she had done with her late husband, Guiseppe Borgese, on a World Constitution published in the 1940s. After the United Nation's speech, Borgese invited the Maltese ambassador to visit the center, a think tank headed by the renowned American educator, Robert

1. A. Leroy Bennett, International Organizations, Principles and Issues (Englewood Cliffs, N.J.: Prentice Hall, 1977), p. 354. 
Maynard Hutchins. ${ }^{2}$ In the next decade, Borgese and Pardo refined the concept of the common heritage of mankind through their writings.

Much like Arvid Pardo, Borgese was a person without a country. She came from a European intellectual family that was uprooted by World War II; a family that lived in exile in the United States and never could return to the intellectual and cultural milieu obliterated by the war. Borgese was the fifth of six children born to the German writer Thomas Mann and his wife Katia. She was born in Munich during the final days of World War I and grew up in a household that was a center for the literati of Europe. As the Nazis came to power in Germany, her father moved away from his early nationalistic orientation and began to criticize the Nazis. ${ }^{3}$. His criticism eventually led him and his family into exile first in Zurich, Switzerland in 1933 and later in the United States.

Borgese was influenced by her father's coterie of exiles who dreamed of creating a world where fascism and Nazism could not sprout anew. The dream infused her with a strong desire at an early age to create some lasting improvement in world governance. At the age of 21 , she married Guiseppe Borgese, a man who was 56 years old at the time. She had read his book, Goliath: The March of Fascism, tracing the rise of Italian fascism and decided he was the man she wanted to

2. Elizabeth Mann Borgese, interview with author, Halifax, Canada, 1 November 1991.

3. Borgese, correspondence with author, 12 February 1992. 
marry although she had never met him. 4 Borgese's deliberate marriage to a husband much older than her in the face of parental disapproval was early evidence of her strong will. Also, her attachment to the abstract ideas that were a part of Guiseppe Borgese's books became a personal trademark that would later be one of the reasons the idea of the "common heritage of mankind" so intrigued her.

During the 1930s and early 1940s, the Borgeses worked together at the University of Chicago where Guiseppe Borgese was a professor of political science and international relations. With the approval of University Chancellor Robert Maynard Hutchins, Guiseppe Borgese brought together a group of intellectuals to draft a proclamation warning of worldwide danger to political freedom. The group, which included Reinhold Niebuhr and Lewis Mumford, wrote and published a book, entitled The City of Man, that described their hopes for a just international order. 5 But the book had little impact. Lewis Mumford later said of it: "Our book sold perhaps 8,000 to 10,000 copies, and at best reinforced the convictions of a minute number of already awakened minds." 6 This criticism could be applied to much of the work that Guiseppe Borgese did. He operated in an intellectual world cut off from both the

4. Borgese interview, 1 Nov. 1991. See also Giuseppe A. Borgese, Goliath: The March of Fascism (NY: Viking Press, 1937).

5. Harry S. Ashmore, Unseasonable Truths: The Life of Robert Maynard Hutchins (Boston: Little, Brown and Company, 1989), p. 206. See also H. Agar, F. Aydelotte, G.A. Borgese et al., The City of Man: A Declaration on World Democracy (New York: The Viking Press, 1940).

6. Ashmore, Unseasonable Truths, p. 207. 
mainstream of American society and European society in which he had grown up.

While these manifestos for creating a just society grounded in international cooperation made little impact, Elisabeth Borgese did not forget them. She became the carrier of the hopes and ideas of both her father and husband when both men died during the 1950s.

In 1964 Hutchins asked Borgese to be the first woman to join the Center for the Study of Democratic Institutions. He wanted her to resurrect the work she and her husband had done in Chicago as founding members of the Committee to Frame A World Constitution. The committee, founded in 1945, had been influenced by the concerns Hutchins had about the development of the atomic bomb, a project in which University of Chicago scientists were playing key consulting roles. ${ }^{7}$ Hutchins went so far as to urge Secretary of State, James F. Byrnes, never to use the bomb. But his pleading did not stop the test explosion at Alamogordo, New Mexico during the summer of 1945 or the attacks on Hiroshima and Nagasaki in August. Hutchins also took a dim view of the newly formed United Nations. He believed it "was fated to join the League of Nations as another monument to postwar disillusionment." 8 This was the backdrop for a suggestion by Guiseppe Borgese and Dean McKeon of the humanities division at the University

7. Ibid., p. 252.

8. Ibid., p. 262. 
of Chicago that they draft a world constitution. Guiseppe Borgese said at the time:

"A world constitution is needed...the deadline being the day, unpredicted but not remote, when the atomic secret will be in other hands. We do not think a world constitution or a preliminary project will be drafted by bureaucratic or diplomatic bodies. Their motions are inhibited by statutory routines; their initiatives, even in this most open-minded of nations, must stop at the dogmatic wall of national sovereignty. 9

These words would be echoed by the work and thought of Borgese's wife long after his death in 1952. She believed that people outside the regular channels of government and diplomacy had a significant role to play in articulating the structure of a new international order. As idealist draftsmen, people like herself would articulate ideas in the hope of moving society forward. These beliefs underpinned the nongovernmental organization that Elisabeth Borgese founded in 1970, The International Ocean Institute, and the annual conferences she has sponsored for 20 years called Pacem in Maribus or Peace in the Oceans. The title of the organization was a deliberate reference to Pope John XXIII Pacem in Terris message. At these conferences, Borgese attempted to expand the constituency for the oceans by involving scientists, geographers, philosophers and political thinkers from around the world in discussions of ocean issues. Some of the people that Borgese brought to these annual conferences included Alva Myrdal, the Swedish cabinet minister and disarmament

9. Ibid., p. 262. 
activist; Jovan Djordjevic, a Yugoslav Constitutional lawyer and one of the architects of the 1963 Yugoslav Constitution;

Hamilton Shirley Amerasinghe, the Ambassador of Ceylon to the United Nations, the chairman of the United Nations Sea-bed Committee and the man who presided over the United Nations Law of the Sea Conference until his death in 1980; Lord Ritchie Calder, a former professor of international relations at the University of Edinburgh; and Norton Ginsburg, a professor of geography at the University of Chicago. 10

As Elisabeth Borgese dusted off the World Constitution written just after World War II, she realized the document was just as idealistic and unrealistic as it had been in the 1945.11 During that period, the constitution had been ripped apart by the Chicago Tribune and called a subversive document that advocated the abolition of the United States as well as all other countries. It was also criticized for challenging the American belief in private property. At the heart of the document was the statement that four elements of life "earth, water, air and energy are the common property of the human race." 12 This idea did not spring newborn from the members of the Committee to Frame a World Constitution. It was a restatement of ancient beliefs expressed in Greek and Roman law that the earth, the water and air belonged to all people. ${ }^{13}$

10. E.M. Borgese, Pacem In Maribus (New York: Dodd, Mead \& Co., 1972), p. 323.

11. Borgese interview, 1 Nov. 1991.

12. G.A. Borgese, Foundations of the World Republic (Chicago: University of Chicago Press, 1953), p. 305.

13. "By the law of nature these things are common to mankind - the air, running water, the sea and consequently the shores of the sea," according to Thomas $C$. 
When Borgese read about Pardo's speech on the common heritage of mankind, it reminded her of the ideas she was contemplating as secretary for the Committee to Frame a World Constitution. Only this time, in 1967, she said she believed that the timing was right to apply the ideas to a real, political world. Borgese recalled in a 1991 interview: " I told Hutchins that I thought if we got involved with the Law of the Sea Conference, we could try out our ideas and bring them down to the political arena and make them less utopian. That is why I got into the Law of the Sea."14

Borgese shrewdly took advantage of the opportunity to push for a new form of ocean regime at a time when ocean affairs were relatively high on the international agenda and also a fairly new field with no established cadre of intellectuals. She carved room for herself in the newly forming arena. It was a time in the development of the field of marine affairs that people with general backgrounds and general concerns for the ocean could become significant players. Prior to 1967, Borgese's interests had not included the ocean, the seabed or mineral mining. In 1975, Borgese wrote:

"The ocean is a laboratory for the development of new and more rational methods of resource management...In the post-industrial era, ocean space may well become the fulcrum of a world economy, just as each semi-enclosed or enclosed ocean basin will be much more than in the past, the fulcrum of regional economic activities... What

Sandars, ed., The Institules of Justinian (Westport, CT: Greenwood Press, 1922), p. 90.

14. Borgese interview, 1 Nov. 1991. 
we are witnessing is a shift from a heartland-continentcentered world view to an ocean-centered world view." 15

This kind of broad, sweeping statement was typical of Borgese's writing. Many of her books and articles discuss a "Marine Revolution," that she compares to the industrial revolution. In the tone of a prophet she warns that this new revolution caused by advances in ocean technology should not proceed in the same way as the industrial revolution. Instead, man should design technological advancements that benefit a large portion of mankind and that do not leave damaged natural resources in the wake. 16 Borgese adopts this same sweeping tone in other writings including, "The sea and the dreams of man," an essay published in 1978 in which she looks for the poetic essence of the ocean and links her own interests in ocean management to her father's ideas about the sea.

...my father's love affair with the ocean must have influenced me powerfully. Rereading his works in my mature years, when I have myself become so deeply involved with the oceans, I find his analysis of the human relationship to nature, and especially the sea, the most profound I have come across. He recognized man's awe in face of the sea's infinity and wildness, in contrast to the constraints of civilization, both equally necessary and complementary; the sea as all and nothing, damnation and redemption, longing and fear; the sea as the dark and

15. Elisabeth Mann Borgese, ed., The Tides of Change: Peace, Pollution and Potential of the Oceans (New York: Mason/Charger, 1975), p. 342.

16. Elisabeth Mann Borgese, The Future of the Oceans: A Report to the Club of Rome (Montreal: Harvest House, 1986), p. 13-42. 
wild element within the artist, within his characters and himself. 17

Although much of her writing contained fanciful and poetic ideas, Borgese also proposed some concrete ideas for ocean management. Among them was the belief that the common heritage regime could provide an "urgently needed" system that was neither capitalism nor communism. ${ }^{18}$ She said the philosophy of "non-ownership" as described by Pardo was a key to this new system. ${ }^{19}$ Borgese also proposed that an ocean development tax be assessed by an international body on all fish caught, oil extracted and minerals produced from the ocean beyond national jurisdiction. Although her idea was proposed by the Canadian delegation in 1971 in the United Nations Committee on the Peaceful Uses of the Sea-bed, it died quickly. 20

Borgese, as a senior research fellow, and Pardo, as a visiting fellow, worked together at the Center for the Study of Democratic Institutions to define the concept of the common heritage of mankind in the late 1960s and early 1970s. Under their definition, the common heritage of mankind was a legal and philosophical concept. ${ }^{21}$ It was to be applied to ocean space, not just for seabed mining of manganese nodules, but also for mining of oil and gas, cooperation in scientific

17. Jacques G. Richardson, ed., Managing the Ocean (Mt. Airy, MD: Lomond Publications, 1985), p. 393.

18. Borgese, Future of the Oceans, p. 2.

19. Ibid., p. 132.

20. Ibid., p. 63-65. See also Canadian proposal of J.A. Beesley, In Elisabeth Mann Borgese, ed., Pacem in Maribus, vol. 2 (Malta: International Ocean Institute, 1971).

21. Arvid Pardo, telephone interview with author, 2 December 1991. 
exploration and environmental protection of the seabed and ocean waters above it. Under the concept, an international body would act as a trustee for mankind - present and future generations - to manage the ocean space.

Together, Borgese and Pardo wrote The New International Economic Order And the Law of the Sea. 22 In this 1976 book they tried to tie the common heritage of mankind to the popular movement for a New International Economic Order led by Latin American and newly emerging African and Asian nations. ${ }^{23}$ The goal of the NIEO was for Africa, Asia and Latin America to move into positions of economic, political and technological power. The exact manner in which this could be done was vague. Those who promoted the NIEO embraced the common heritage of mankind as will be explained in greater detail in chapter four. They supported the common heritage idea because of the stated goal of sharing governance of a large area of the ocean, sharing technology needed to explore and mine the seabed and, finally, using profits made from selling the minerals for Third World development. In their book and in subsequent writings, Pardo and Borgese called the common heritage of mankind a broad and flexible concept. They said that the world was in a new era where "neither sovereignty

22. Arvid Pardo and Elisabeth Mann Borgese, The New International Economic Order And The Law of the Sea (Malta: International Ocean Institute, 1976), p. 4. 23. United Nations, General Assembly, Res. 3281 (XXIX), 12 December 1974; U.N. Gen. Ass., Res. 3201 and 3202 (S-VI) 1 May 1974. 
nor freedom (of the seas) are a suitable basis for a legal regime." 24

Borgese often alluded to this world between two competing ideologies. For example, she believed ocean management could forge a new path between socialism and capitalism just as she believed it could establish a common space regime that was neither sovereignty nor freedom of the seas. The difficulty was figuring what is this in-between regime. In this area, Borgese's sweeping approach frustrated the practical-minded person.

However, Borgese encouraged Pardo to articulate more clearly his idea and she also took on the role of publicizing Pardo's idea. For example, she noted in a 1991 interview that Pardo had deliberately used the word "heritage" instead of "property" when he first spoke of a concept for managing the ocean. He would later explain that he did not use the word "property" because he believed it carried implications of power and privilege. 25 Borgese's earlier work with the Committee to Frame a World Constitution had promoted the idea of common property. But she said she preferred Pardo's idea that ocean space would not be owned, but would be governed for current and future generations. During the years that they worked together, Borgese adopted many of Pardo's ideas and influenced him by suggesting that the common heritage of

24. Pardo and Borgese, The New International Economic Order, p. 4.

25. Pardo interview, 2 Dec. 1991. 
mankind concept should be a concept for other systems of government on land and sea, she told Pardo.26

Over the decade from 1970 to 1980, Pardo's writing became increasingly pessimistic about what was happening to the common heritage concept. He began with optimism. In 1968, a year after his United Nations speech, Pardo published an article, "Who Will Control the Seabed?,"27 which strongly advocated that the common heritage include three major resources; hydrocarbons, calcareous ooze, which could be used to manufacture cement, and manganese nodules. He also predicted that ocean technology was proceeding so quickly that man would be able to live beneath the ocean in communities within the century. As with his speech, Pardo urged the creation of an international regime to manage, govern, exploit and explore the deep seabed. The article gave no specifics on where Pardo wished the international deep seabed to begin. One noticeable development in the article was that Pardo was more vocal about the concerns of lesser developed countries than he had been in his 1967 speech. He wrote that the deep seabed should be mined for minerals in a way that did not seriously injure the economies of nations that produced the same minerals on land. Lesser developed countries were concerned that a seabed source of minerals would flood markets and lower prices for their raw mineral exports.

26. Ibid.

27. Arvid Pardo, "Who Will Control the Seabed?" Foreign Affairs, vol. 47, no. 1 (1968): p. 124. 
Pardo's 1968 article was a rallying call for his suggested United Nations resolution on the common heritage of mankind the Dec. 17, 1970 "Declaration of Principles Governing the SeaBed and the Ocean Floor, and the Subsoil Thereof, beyond the Limits of National Jurisdiction. 28 The resolution declared the common heritage was "an area of the sea-bed and the ocean floor, and the subsoil thereof, beyond the limits of national jurisdiction, the precise limits of which are yet to be determined." It included all but one of the five initial points that Pardo made when he defined the common heritage regime in his 1967 speech. The resources of the common heritage were to be used for the benefit of all mankind, the deep seabed area was to be used exclusively for peaceful purposes, the international regime would have jurisdiction; but no person or state would have sovereignty and the fruits of the deep seabed would be used to assist the developing nations.

The resolution differed from Pardo's speech in that it pushed for international cooperation in scientific research, but did not stipulate that one nation's research in the deep seabed should be shared with other nation as Pardo had proposed. The resolution also advocated a "healthy development of the world economy" that would "minimize any adverse economic effects caused by the fluctuation of prices of raw materials.." The resolution also included stipulations pushed by the American government and other maritime powers that nothing in the common heritage concept would affect the "legal status of the

28. U.N., G.A., Res. 2749 (XXV), 17 December 1970. 
waters superjacent to the area or that of the air space above those waters." The exploration and exploitation of the resources of the seabed would be governed by an "international regime to be established." Finally, the resolution called for the convening of a conference on the Law of the Sea. To prepare for such a conference, the United Nations created a Sea-bed Committee in 1968 to design an international regime.

Before the Law of the Sea conference started in 1973, Pardo sounded his disappointment with the Sea-Bed Committee and his pessimism about the future of the common heritage. He became disappointed in the early 1970 s as he saw that lesser developed countries were more interested in claiming large economic zones that extended their ocean jurisdiction than they were in setting up a large common heritage regime. As some of these lesser developed countries campaigned for 200-mile wide economic zones, they were advocating removal of the most valuable seabed resources - oil and gas - from what Pardo had hoped would be an international zone. In an August 8, 1973 speech, Pardo said he was disgusted with developing nation-sponsored proposals to expand coastal state sovereignty. In a sarcastic manner, he noted that: "There would still exist some marine plants, some floating seaweed, a few migratory species of fish and sea mammals and some manganese nodules outside the area under coastal State sovereignty of exclusive jurisdiction." 29 He went on to predict that the hunger by

29. Arvid Pardo, "A Statement on the Future Law of the Sea in Light of Current Trends in Negotiations," Ocean Development and International Law, vol. 1, no. 4 (1974): p. 324. 
coastal states for larger and larger jurisdiction over the ocean would result in a Law of the Sea conference slogan of "total irresponsibility within total sovereignty for the common benefit of mankind."

Like Borgese, Pardo believed that the advance of ocean technology demanded a new legal concept for managing the ocean. In his view the concept of freedom of the seas would no longer work for the deep oceans; neither would the concept of sovereignty in which the remaining ocean space was carved up among nations. Instead, he called for a new way of thinking without outlining in concrete terms what it should be. "World federalists and academicians might believe the answer lies in the creation of a supranational authority for the oceans, to which States would surrender their powers," Pardo noted, but this was not "politically acceptable" nor "desirable." Instead, he advocated a "flexible institutional framework within which solutions can be sought to the increasingly serious problems which are arising in ocean space." He wanted to constrain both sovereignty and freedom and introduce a new element international cooperation. 30 Pardo elaborated on the need for cooperation and sharing of information and technology in on July 26, 1973 statement to the United Nations Social and Economic Council. 31

By the time the United Nations Conference on the Law of the Sea began in late 1973, Borgese and Pardo were on the

30. Ibid., p. 330.

31. Arvid Pardo, The Common Heritage: Selected Papers on Oceans and World Order, 1967-1974 (Malta: Malta University Press, 1975), p. 305-310. 
periphery of the debate. Pardo lost his ambassadorship in 1970 because of a change of government in Malta. Although he was named an advisor to the assistant secretary general of the United Nations, he felt powerless during the conference. 32 His writing during this period from 1973 to the end of the conference in 1982 became increasingly bitter and pessimistic culminating with an article outlining the failure of the conference to give birth to a true and workable regime for the common heritage of mankind. 33

Borgese, on the other hand, remained an enthusiastic advocate of the common heritage regime. By the start of the conference, she had formed the International Ocean Institute, a privately-funded nongovernmental organization that put on international conferences, published papers on how the ocean should be governed and later ran training programs in ocean science and political issues for Third World leaders. She participated in the United Nations Conference on the Law of the Sea as a nongovernmental representative until 1974.

Frustrated with her position as a representative from an NGO, Borgese sought official diplomatic status. She wanted access to the closed sessions where much of the conference work was done. Borgese called on her international network of contacts to gain a seat as a national representative. Peter Jankowitsch of the Austrian delegation offered her a position on the delegation

32. Pardo interview, 2 Dec. 1991.

33. Arvid Pardo, "An Opportunity Lost," In B. H. Oxman, D.D. Caron and C.O. Buderi, eds., Law of the Sea: U.S. Policy Dilemma (San Francisco: Institute for Contemporary Studies, 1983), pp. 13-26. 
of that nation. ${ }^{34}$ Using her status as a delegate, Borgese criticized negotiators for narrowly concentrating on an international regime for manganese-nodule mining. She urged the conference to consider all seabed resources especially oil and gas to be part of the common heritage. 35 Despite appointment as a delegate, Borgese was not regarded as a powerful force at the conference. Policy-making was largely out of her hands. 36

In addition to Borgese, a small group of Americans, members of church and other NGOs, took up the Law of the Sea as their cause. Like Borgese, these champions of the common heritage did not come from marine or scientific backgrounds. They were idealists, social reformers and dreamers.

Sam and Miriam Levering had been advocates of what they called "world order" since the end of World War II. They heard about the United States Draft Proposal on the Law of the Sea in 1972 and were urged by fellow Quakers to lobby for the treaty within the United States government. Said Miriam in a 1991 correspondence: "We ended up volunteering to do this work, and stayed with it. We spent much time in Washington, New York, Geneva; formed two organizations, one for lobbying called The United States Committee for the Oceans and a year later, the Ocean Education Project."37

34. Borgese interview, 1 Nov. 1991.

35. Ibid.

36. Pardo interview, 2 Dec. 1991 and Marne Dubs, personal interview with author, Narragansett, RI, 23 July 1991.

37. Miriam Levering, correspondence with author, 4 October 1991. 
The Leverings joined with the United Methodist Women's group to publish a newsletter called Neptune during the conference. Miriam said: "We were motivated by our religious convictions that society at any level rests on the three Biblical principles of law, justice and love. As communication has made the world a community, it became clear that no community can exist without some rules to prevent and settle conflict. Our interest in the environmental aspects of the convention came from a religious belief in the integrity of Creation."

The Leverings pushed for a large area of the ocean to be considered the common heritage of mankind. At the start of the conference, there was discussion about including all the sea floor beyond the three mile territorial sea in the common heritage. But this idea quickly disappeared as coastal nations latched onto the idea of creating 200-mile wide exclusive economic zones off their coasts. The exclusive economic zone was negotiated at the conference and allowed for each coastal nation to declare the resources in a 200-mile band of ocean to be theirs to manage and exploit. ${ }^{38}$

The Quaker United Nations staff in Geneva also participated in the Law of the Sea discussions by offering weekly panel discussions at the conference sessions in Geneva. The discussions brought together delegates, scholars, scientists

38. David J. Attard, The Exclusive Economic Zone in International Law (Oxford: Clarendon Press, 1987). See also Francisco Vicuna, ed., The Exclusive Economic Zone: A Latin American Perspective (Boulder Co.: Westview Press, 1984). 
government officials and members of nongovernmental organizations. 39

Barbara Weaver, another citizen advocate of the common heritage, was teaching social studies in a junior high school in Ohio when she developed an interest in the Law of the Sea. She took her class on a field trip to the United Nations in 1974 and the students met with diplomats about to depart for the conference session in Caracas. Weaver was impressed by the excitement of diplomats preparing for a conference that brought together more nations of the world than had ever met. When she returned to Ohio, she decided to get more involved with the Law of the Sea and took an internship with the Women's Division of the General Board of Global Ministries of the United Methodist Church.

The Law of the Sea brought together a number of Weaver's concerns - the ocean, social justice, peace and hunger issues. In 1976, the Methodists founded a Law of the Sea Project and hired Weaver to work full-time on it in Washington. The Methodist Church became interested in the issue because it fostered cooperation among nations in a peaceful forum and because the church believed that ocean wealth from mineral mining might finance a more just type of development in the Third World. Weaver joined with the Leverings to publish Neptune during the various sessions of the conference. The small NGOs also hosted speakers at forums

39. Lawrence Juda, ed., The Seventh Session of the Third United Nations Conference on The Law of the Sea: Summary of Remarks of the Speakers, 11 April to 9 May 1978. 
to help build an awareness among delegates and interested public of various issues discussed in treaty negotiations.

Weaver helped publish a 100-page handbook that was used to explain the Law of the Sea issues to church groups in America's heartland. 40

"I have always felt that the idea of the common heritage is an important one," Weaver said in 1991. "Not only is there a benefit to holding resources in common, but also the idea of holding resources for the future was exciting. But the mechanics of figuring out how to do this ground people down."41

As advocates for the common heritage, Weaver and the Leverings knew they were fighting a difficult battle. There was strong tension between their idealism and the realism of the American diplomats who reluctantly endorsed the idea of an international regime for the deep seabed.

"I really thought the deep seabed was a small part of the world. I really thought the industrialized nations would let that piece go to benefit the poorest of the poor nations," Weaver said. "But they were concerned about precedent. In the end, I think it was too radical an idea." Weaver left the Law of the Sea Project in 1981. The Methodist Church closed the project in 1984.

40. Barbara Weaver, Lee Kimball, Miriam Levering, Arthur Paterson, James Bridgman, Barbara Bachtell and Sister Mary Beth Reissen, Voyage to Discovery (1977), an unpublished loose-leaf manual used to explain the Law of the Sea to church and community groups.

41. Barbara Weaver, personal interview with author, New York City, 20 September 1991. 
"There was a brief window of possibility of real cooperation," Weaver said. But that moment passed quickly. Weaver places that moment in 1974 in Caracas. "That was when people talked seriously about the common heritage of mankind. Then the roadblocks got thrown up, awful fast," she said.

John Logue waged his own campaign for the common heritage of mankind, as director of Villanova University's World Order Research Institute and as a member of the World Federalists. In 1980, Logue renamed the institute he directed, the Common Heritage Institute. Like Borgese, with whom he worked, Logue maintained that the idea of the common heritage was larger than the oceans and should apply to other natural resources in the future. He argued that the ocean's mineral wealth could provide a substantial financial base to assist Third World development, alleviate world hunger, fund ocean environmental protection and give the United Nations its first independent source of income. In newsletters, speeches and the introduction to a book he edited, entitled,The Fate of the Oceans, Logue said that the major problem with the United Nations was its lack of a reliable source of revenue to do international work. Logue suggested that revenue from mining oil and gas and seabed minerals should provide that source.

"Long ago, in The Federalist, Alexander Hamilton said that a person does not truly will an end or objective unless he also 
wills the means to accomplish that objective," wrote Logue in Fate of the Oceans. 42

Throughout the nearly nine year Conference on the Law of the Sea, Logue published a newsletter, the World Order Research Institute Report, which detailed conference happenings and promoted ideas he supported. Like others on the nongovernment side of the aisle, Logue was a maximalist. To him, the common heritage was a philosophical concept endorsing the benevolent management of ocean space by an international regime for current and future generations. Logue fought against the 200-mile exclusive economic zone, maintaining that it took a sizeable chunk out of the most valuable land and resources from the common heritage. "The 200 mile EEZ means the death of the common heritage," Logue wrote. ${ }^{43}$ Logue was more interested in the original draft treaty proposed by President Nixon in 1970 which would have created an International Seabed Area beyond the 200-meterisobath. ${ }^{44}$ This area would have two parts: Ocean areas between the 200 meter isobath and the edge of the continental margin would be in the International Trusteeship Area. This area would be managed by the coastal nation, which would share revenues from resources with an international body. The

42. John Logue, ed., The Fate of the Oceans (Villanova: Villanova University Press, 1972), p. xvii.

43. World Order Research Institute, World Order Research Institute Report (July 1975), pp. 1-4.

44. For copy of U.S. Draft Convention on the International Seabed Area see appendix of Lawrence Juda, Ocean Space Rights: Developing U.S. Policy (New York: Praeger Publishers, 1975), pp. 205-249. 
deep sea beyond this zone would be completely managed by an international ocean regime.

Logue promoted what was called the Barba Negra Formula, named for a tall ship that he, other NGOs and diplomats, sailed in New York harbor to promote the common heritage concept. Similar to the Nixon proposal in concept, the formula called for an even larger area where ocean wealth would be shared between nations and the international community. It proposed the sharing of revenues from mineral mining and oil production in the portion of ocean space from a 12-mile territorial sea to the end of the 200-mile exclusive economic zone. Logue used his newsletter to promote this formula and later to advocate a proposal by Nepal Ambassador Shailendra K. Upadhyay to create a Common Heritage Fund based on a similar revenue-sharing scheme. 45

Logue also used his newsletter to prod Third World leaders to take a strong role in promoting the common heritage. "Unless the Third World takes a major responsibility for reviving the common heritage of mankind there is every reason to believe that the concept and the bright promise inherent in it will die," Logue wrote as early as 1975.46

It is difficult to assess the effect these fledgling nongovernmental organizations had on the development of the common heritage of mankind concept. They promoted

45. World Order Research Institute, World Order Research Institute Report (March 1978), p. 1.

46. World Order Research Institute, World Order Research Institute Report

(February 1975), p. 1. 
discussion of the idea even when delegates were inclined to ignore the concept or bog it down with technical disputes. Borgese tried to broaden the constituency for the common heritage concept by inviting international thinkers to annual conferences. Although these conferences were sometimes criticized as glorified international cocktail parties, they did produce a body of writing that spread the philosophy and the rhetoric of the common heritage. These conferences also connected the ocean with other global issues such as disarmament, population issues, pollution and hunger. 47

The small membership of the NGOs did not seem to deter them from sponsoring numerous forums and producing volumes of written material during and after the conference. Logue, Borgese and the Leverings each sponsored forums in which diplomats, Third World leaders, scientists and economists spoke on ocean issues. They realized that the common heritage idea had few strong spokesmen among the United States delegation. Usually, their strongest allies were among delegates from Africa and Asia. Logue and Borgese also lamented that the delegates did not engage in much discussion of what the common heritage of mankind would mean, leaving this type of discussion to NGO forums. 48

One of the political weaknesses of common heritage advocates was that they spoke for handfuls of like-minded

47. Elisabeth Mann Borgese, ed., Pacem in Maribus (New York: Dodd, Mead \& Co., 1972).

48. Borgese interview, 1 Nov. 1991. See also World Order Research Institute, World Order Research Institute Report (October 1974), p. 1. 
people not large grass-root organizations. There was no groundswell of support for the common heritage of mankind in the American heartland. Borgese was a one-person-show in many ways although she had an extensive network of international scholars and diplomats to draw on for Pacem in Maribus conferences. She was well-connected internationally because of her work with Hutchins and her celebrity as the daughter of an internationally known writer. Borgese also had other international ties because she was a member of the Club of Rome, an informal organization of scientists, educators, economists and industrialists founded in 1968 to promote global policy. 49

The common heritage advocates also lacked nongovernmental counterparts from the lesser developed countries in Africa, Latin America or Asia. The reason may be that people in these countries did not have the money, time or see the direct relevance to their lives of rallying for the common heritage of mankind. The concept was abstract and it was difficult for most people to make the connection between a seabed regime and solving world problems of poverty, hunger and underdevelopment. The people that rallied to this idea were intellectuals, social justice activists and government representatives from the Third World who could make the abstract connection, had a deep belief in international cooperation or saw an advantage to supporting the idea. But

49. See Donella Meadows, Dennis Meadows et al., The Limits of Growth: A Report for the Club of Rome's Project on the Predicament of Mankind (New York: Universe Books, 1972). 
because the NGOs had no counterparts from the Third World, they can be compared to abolitionists of the 19th century certain they knew what was right for a part of the world with which they were not intimately familiar. As with the abolitionists, these "do-gooders" were not always understood or respected even by the people they claimed to be supporting.

But the small band of NGOs did raise a strong voice for internationalism and a global perspective at a conference where nationalistic concerns dominated.50 At the close of the Law of the Sea conference, Ambassador Tommy T. B. Koh of Singapore, the conference president, thanked the Neptune Group in particular for providing the conference with three services - bringing independent sources of information on technical issues, assisting representatives from developing countries understand the new technology that prompted talk of seabed mining and providing places for delegates to meet and discuss ideas. 51

The NGOs also began efforts to broaden the constituency for the oceans. Despite its mammoth size - covering more than 70 percent of the earth - the ocean, especially the area not connected to the coast, does not have a strong and large constituency. The NGOs at the conference were the beginnings of a citizen constituency for the ocean which has grown in the 1980 s and 1990s with the help of charismatic international

50. J.N Barnes, "Non-governmental organizations: Increasing Global Perspective," Marine Policy, vol. 8 (1984): p. 171-81.

51. Martin I. Glassner, Neptune's Domain: A Political Geography of the Sea (Boston: Unwin Hyman, 1990), p. 132. 
organizations such as Greenpeace and also more specific causes than a common heritage regime to rally around such as the extinction of whales. 52

52. Anthony D'Amato and Sudhir K. Chopra, "Whales: Their Emerging Right to Life,"American Journal of International Law, vol. 85 (1991): p. 21-62. 
Chapter III - The Marriage of the New International Economic Order and the Common Heritage of Mankind

While leaders of some NGOs were devoted advocates of the concept of the common heritage of mankind, the most powerful promoters of the common heritage at the United Nations Conference on the Law of the Sea were delegates from the newly independent nations of the developing world. These delegates from African, Asian and Latin American nations were powerful for two reasons. They had the majority of votes because there were more developing countries than industrialized nations. They also had a moral argument; their years of colonial subjugation allowed them to appeal to the guilt of the industrialized world. Unlike many of the industrialized nations and some of the socialist countries that reacted to Pardo's proposal with suspicion and reservation, these nations embraced the concept and adopted it as a piece of a larger movement called the New International Economic Order. 1

These national leaders defined the common heritage of mankind so that it would fit with the broader New International Economic Order goals of restructuring the international economy. The NIEO was announced and defined in several United Nations resolutions including one passed on

1. Lawrence Juda, ed., The Seventh Session of the Third United Nations Conference on the Law of the Sea: Summary of Remarks of the Speakers, Quaker United Nations Office Report, 11 April - 9 May 1978. 
Dec. 12, 1974 called the Charter of Economic Rights and Duties. ${ }^{2}$ A desire for a New International Economic Order was also articulated at the UN Conference on Trade and Development (UNCTAD). The growing number of developing nations established this organization in 1964 because they wanted to have more than a majority of the votes in the United Nations. They desired some power over international trade. ${ }^{3}$

Forces favoring what became known as the NIEO had been gaining momentum since the end of colonial rule in Africa, Asia and Latin America. By the late 1960s, these countries had begun to challenge the classic economic system that dominated the global economy. The new nations believed they had obtained political freedom, but were not economically free of their colonial masters. They saw the laissez-faire economic system as promoting a form of neo-colonialism in which Third World countries continued to supply the developed world with raw materials, while being forced to pay high prices for finished products. ${ }^{4}$ As these nations watched their international debt grow, they saw the gap between the wealthy, industrialized nations and their countries widening.

The goals of the New International Economic Order were to restructure the economic system in the areas of trade,

2. U.N., G.A., Res. 3281 (XXIX) 12 December 1974. See also U.N., G.A., Res. 3201 (SVI) 1 May 1974.

3. P.N. Agarwala, The New International Economic Order: An Overview (New York: Pergamon Press, 1983), pp. 112 and 167. See also Edwin Reubens, ed., The Challenge of the New International Economic Order (Boulder: Westview Press, 1981 ).

4. Jagdish N. Bhagwati, ed., The New International Economic Order: The NorthSouth Debate (Cambridge, MA: The MIT Press, 1977), p. 4. 
finance, technology transfers, and political relationships as a way to close the wealth gap between developing countries and the developed world. The Declaration of the Establishment of a New International Economic Order notes that "the developing countries, which constitute 70 percent of the world population, account for only 30 percent of the world's income."5 The developing countries believed the common heritage of mankind could help them close the gap.

An international ocean regime for a vast portion of the globe could be designed to give the lesser developed countries a stronger role to play than they had in any other international organization, including the United Nations which was formed before these countries were born. The mining of a new resource could produce profits to assist development projects in the Third World. The common heritage of mankind also offered a chance to create new international law. ${ }^{6}$ They hoped it would be a "law of cooperation" among nations. ${ }^{7}$ They wanted it to be a departure from existing international law which these nations perceived as designed to protect private interests working abroad and they wanted it to address human welfare issues. 8

5. U.N., G.A., Res. 3201.

6. Milan Bulajic, Principles of International Development Law (Boston: Martinus Nijhoff Publishers, 1986).

7. Boleslaw Adam Boczek, "Ideology and the Law of the Sea: The Challenge of the New International Economic Order, Boston College International \& Comparative Law Review, vol. vii, no. 1 (1984): p. 5.

8. Lawrence Juda, "UNCLOS III and the New International Economic Order," Ocean Development and International Law Journal, vol. 7, no. 3-4, (1979): p. 223. 
Leaders of the newly emerging nations also recognized that the common heritage concept was evolving, and that they would have a chance to put their imprint on it. Arvid Pardo and Elizabeth Mann Borgese encouraged leaders of lesser developed nations that the concept was well-suited to the New International Economic Order. ${ }^{9}$

Scholars and leaders of developing countries defined the common heritage as a new concept in international law, a departure from all that had come before. This stand was bound to make western nations that were more comfortable with incremental change uneasy. For example, Shigeru Oda, the Japanese delegate to the United Nations Sea-bed Committee, the body established by the United Nations in 1968 to study ways to create a seabed regime, wanted to be sure that the common heritage concept did not supplant the age-old international legal concept of freedom of the high seas. ${ }^{10}$ In a statement on March 25, 1969 in the Sea-bed Committee, Oda said: "To ignore that principle will inevitably result in chaos and thus inhibit the optimum use of the seabed for the benefit of all mankind." 11

9. Elisabeth Mann Borgese, "The New International Economic Order and the Law of the Sea," San Diego Law Review, vol. 14, no. 3 (1977): p. 548 . See also Arvid Pardo, "Building the New International Order: The Need for a Framework Treaty," In A. Dolman, ed., Global Planning and Resource Management (New York: Pergamon Press, 1980) pp. 195-201.

10. Under the principle of freedom of the seas no state may subject any part of the high seas to its sovereignty. This principle was customary law in the 18th century and became part of treaty law in Article I of the 1958 United Nations Conference on the Law of the Sea, Convention on the High Seas, 29 April 1958, 13 U.S.T. 2312. 11. Shigeru Oda, ed., The Law of the Sea in our Time: The United Nations Sea-bed Committee, 1968-1973 (Leyden: Sijthoff, 1977), p. 57. 
To the developing countries, the principle of freedom of the seas was part of the old order. It was an ocean law equivalent of laissez-faire economics that allowed the powerful to take a larger share of fish, oil and other ocean resources than that taken by the lesser developed nations. It did nothing to ensure equal access to natural resources. The debate became whether the principle of freedom of the seas would be replaced by the emerging principle of the common heritage in the deep seabed or whether the two could exist at once.

The developing country definition of the common heritage of mankind differed from Pardo's original definition in considering the deep seabed a type of "common property" that would by owned by "mankind." Christopher Pinto of Sri Lanka explained to participants at a 1978 Law of the Sea Workshop at the University of Hawaii that the common heritage of mankind

"...means that those minerals cannot be freely mined. They are not there, so to speak, for the taking." 12

The idea that the seabed is the exclusive property of Mankind is expressed in the Moratorium Resolution passed in 1969 by the United Nations General Assembly prohibiting exploration and exploitation of the deep seabed by any nation

12. Said Mahmoudi, The Law of Deep Sea-Bed Mining (Stockholm: Almqvist \& Wiksell International, 1987), p. 159. See also Christopher Pinto, "Toward a Regime Governing International Public Property," In A. Dolman, ed., Global Planning and Resource Management (New York: Pergamon Press, 1980), pp. 202-224. 
pending the establishment of an international regime. 13 The resolution was passed over the objections of a number of developed countries including the United States, Canada, the United Kingdom, France and the Netherlands. It states that "pending the establishment of the aforementioned international regime: a) States and persons, physical or juridical, are bound to refrain from all activities of exploitation of the resources of the area of the sea-bed...beyond the limits of national jurisdiction." 14

A representative from the United States to the United Nations called the resolution counterproductive, unnecessary and charged that it was ludicrous for the Third World to believe a great seabed land grab was about to happen. The U.S. also said such a moratorium resolution set a discouraging tone for commercial development of mining technology at a time when private industry needed encouragement. The United States accused promoters of the resolution with trying to slow seabed exploration and exploitation technology and claimed that such a resolution encouraged nations to make "unjustifiably expansive" ocean space claims in order to remove more territory from a future international regime. 15

The moratorium was promoted by Garcia Robles, the representative from Mexico to the United Nations, who called it

13. U.N., G.A., Res. 2574D (XXIV) 15 December 1969. Reprinted in Shigeru Oda, ed., The International Law of the Ocean Development: Basic Documents (Leyden: Sijthoff, 1972), p. 43.

14. Ibid.

15. U.N., G.A. (A/PV.1833), 15 December 1969. 
simply a repetition of what had already been stated in previous resolutions. Robles said the moratorium was needed to protect the seabed from people taking advantage of the legal vacuum until the regime was developed. Araujo Castro, the United Nation delegate from Brazil, also said it was logical to postpone any seabed activities. ${ }^{16}$ The resolution was adopted by a vote of 62 to 28 , with 28 abstentions.

Developing countries trumpeted the common heritage of mankind regime while they also took up the cause of extending national jurisdiction in the ocean. By supporting both a highly international concept and a nationalistic concept of extending jurisdiction, the developing countries were ideologically conflicted. ${ }^{17}$ What they truly wanted was to control more of the world's resources and they looked for the most expedient ways to achieve this control.

By promoting 200-mile-wide exclusive economic zones, some of the coastal Latin American and African delegates to the conference differed markedly from Pardo and NGO advocates of the common heritage. This zone would be claimed by the coastal state for exclusive fishing, mining and other resource use. The idea had emerged from Africa and Latin America. In June 1972, the African States Regional Seminar on the Law of the Sea in Yaounde endorsed a 200-mile economic zone.18 During the same month, a group of Latin American

16. Ibid.

17. Boczek, Ideology and the Law of the Sea.

18. Reprinted in U.N., G.A., Official Records, Supplement 21, (A/8721), 1972, p.

70. 
nations issued the Declaration of Santo Domingo which called for a patrimonial sea to give states sovereign rights over a large new ocean territory yet to be demarcated.19

The idea of the exclusive economic zone conflicted with Pardo's hopes that nations would move beyond sovereignty as a primary goal and create a large common heritage area with oil and mineral resources. However, the zone fulfilled one of the stated New International Economic Order goals of nationalizing natural resources. By pushing for nationalized ocean space, the lesser developed countries with coastlines would be securing these resources for themselves at a time when entrepreneurs from developed countries wanted to drill for oil or fish off the coasts of countries with abundant resources. The Latin American nations led by Peru, Chile and Brazil were the strongest proponents of expanding a nation's ocean claims. But many African coastal states also saw this as a positive move. The lesser developed countries without coasts and with limited or no continental shelves did not favor extending ocean jurisdiction. 20 However, these nations joined with other developing countries to support the idea of extending jurisdiction because they did not want to side with developed countries that opposed the ocean enclosure movement. 21

19. Ibid. p. 73 .

20. R.P. Anand, Legal Regime of The Sea-Bed And The Developing Countries (Delhi: Thomson Press Ltd., 1975), p. 159.

21. Boczek, Ideology and the Law of the Sea, p. 13-15. 
Boleslaw Boczek has concluded that the "rhetoric of the NIEO" was used to mask pure and simple "nationalism." By promoting the exclusive economic zone, these nations were urging the removal of one third of ocean space from what would be the common heritage of mankind. In addition, that third of ocean space contained most of the valuable oil and gas deposits and nearly 80 percent of the fish stocks. In the end, the adoption of the exclusive economic zone benefited developed countries more than its Third World promoters. Twenty five countries control 76 percent of the world exclusive economic zone.22 The United States and France lead the world in square miles of exclusive economic zone. 23

The primary conflict between the NIEO and the common heritage of mankind regime for the ocean was economic. Some of the founders of the NIEO were representatives of African and Latin American nations that had mineral mines within their land borders. When they talked about nationalizing natural resources they were speaking primarily about controlling these mines and the wealth that came from them. They also talked about forming cartels in order to gain more economic power in international trade. 24 They looked to the Arab Organization of Petroleum Exporting Countries' embargo

22. Ibid., p. 14.

23. Lewis Alexander, Navigational Restrictions Within the New LOS Context: Geographical Implications for the United States (Peacedale, RI: Offshore Consultants Inc., 1986), p. 88.

24. Kenneth E. Boulder, "Cartels, Prices, and the Grants Economy," In Edwin Reubens, ed., The Challenge of the New International Economic Order (Boulder: Westview Press, 1981). 
as a role model for building an economic power base and controlling prices. The problem was how could these nations support an international regime devoted to increasing exploitation of minerals from the seabed. It was obvious that these minerals would compete on the world market with the minerals mined within some of the developing countries. The competition might depress prices or even shift the mining business permanently from land to sea.25

How could the developing countries resolve the major conflicts between devotion to a common heritage regime for mining the seabed and a desire to limit or, at least, control the supply and prices of a new source of minerals on the world market? How could these nations resolve their desire to promote a new form of internationalism and at the same time grab as much ocean space as was possible for their particular nations? These conflicts would become more apparent during the ten years of negotiations on a Law of the Sea Treaty. They would be accommodated in the treaty. But the accommodation would add a level of complexity to the treaty which would make parts of it completely impractical.

25. United Nations, Report by the Secretariat of the United Nations Conference on Trade and Development, Implications of the Exploitation of the Mineral Resources of the International Area of the Sea-Bed: Issues of International Commodity Policy, (TD/B/C.1/170), 8 January 1975. 


\section{Chapter IV - The Concept is Translated into Policy}

The intellectual idea of applying the common heritage concept to the world's oceans moved into the policy arena at the Third United Nations Conference on the Law of the Sea (UNCLOS) in 1973. As with any intellectual concept, the journey transformed the lofty idea into a much different practical policy. A whole new set of people dominated the policy-making arena than had been part of the idea arena. Although some of the idea people, including Borgese and Pardo, continued to write, participate in discussions and closely observe UNCLOS, they had little effect on the treaty-making process.

This chapter describes the aspirations of developing nations for a common heritage policy and the aspirations of the United States, the leading developed nation and originally one of the strongest proponents of a Law of the Sea Conference, for a seabed mining regime. The developing nations and the United States were caught in a struggle over translating the idea into a workable mining regime. Some of the key points in this struggle included a 1976 compromise put forward by Secretary of State Henry Kissinger; the work of Elliot Richardson, President Jimmy Carter's negotiator at UNCLOS; the role of the American Congress in influencing the international agreement and President Reagan's 1982 decision to reject the seabed regime. This chapter will review the current status of the seabed portion of the treaty, the preparatory commission 
meetings and current and future economic viability of seabed mining.

The geographic limitations of the common heritage regime were defined quickly at UNCLOS. Borgese had suggested an international ocean regime that governed ocean space - the waters and the seabed - beyond the territorial sea, but negotiations limited the common heritage to the deep seabed and subsoil. The waters above would continue to be governed by the concept of freedom of the high seas. Early in the conference, nations demanded a 200-mile exclusive economic zone and coastal state rights to exploit the living and nonliving resources of this band of ocean space as well as the continental shelf beyond 200 miles. 1 When nations agreed to this, they eliminated the chance that offshore oil - found predominantly beneath the continental shelf - would be part of the common heritage. Pardo lamented the loss of this valuable resource to the world community and warned that it stripped the common heritage of its value and doomed the regime to insignificance. ${ }^{2}$

By the start of UNCLOS, the world's nations had agreed that the deep seabed and its resources were the common heritage of mankind, a shared resource. This step was accomplished in the 1970 Declaration of Principles passed as a

1. Bernard H. Oxman, "Summary of the Law of the Sea Convention," In Oxman, D. Caron and C. Buderi, eds., Law of the Sea: U.S. Policy Dilemma (San Francisco: Institute for Contemporary Studies, 1983), p. 153.

2. Arvid Pardo, The Common Heritage: Selected Papers on Oceans and World Order 1967-1974 (Malta: Malta University Press, 1975), p. xii. 
United Nations General Assembly resolution. ${ }^{3}$ But it was a much more difficult step for nations with highly different economic systems and political ideologies to design an international economic organization to oversee the extraction of minerals from the seabed and the division of revenues.

The United Nations conference, a body of more than 3,000 delegates from 159 nations, the largest legislative forum ever convened, assigned the duty of drafting a seabed regime to Committee One. Committee Two worked on issues of national jurisdiction, economic zones, territorial sea, straits and continental shelves, while Committee Three addressed marine pollution, scientific research issues and technology transfer. The Law of the Sea convention attempted to tackle all the significant ocean issues that had emerged to write a "constitution for the oceans." 4

The conference was held primarily because the United States and other maritime powers were concerned with "creeping jurisdiction," the phrase used to describe a trend in which coastal states push their jurisdiction seawards, causing navigational and overflight barriers to maritime powers. The United States began pushing for a Law of the Sea conference in the late 1960s.5 In addition, the developed countries wanted to address concerns about dwindling fisheries, the marine environment, and oil exploration. Initially, American policy-

3. U.N., G.A., Res. 2749 (XXV), 17 December 1970.

4. William Wertenbaker, "A Reporter at Large: The Law of the Sea," New Yorker (Aug. 1, 1983): p. 39.

5. Elliot Richardson, telephone interview with author, 7 May 1992. 
makers believed separate treaties on these diverse issues would be the best approach. However, they realized these narrowly-focused treaties would not interest and therefore discourage participation by a large number of the new, predominantly Third World nations. So they considered adding issues that interested the new nations, including the common heritage regime for seabed mining and revenues from it. In 1969, the United Nations announced the conference would take up a broad array of issues and aim for a "package deal." 6

By the start of the conference, delegations of a number of developing countries that served on the UN Sea-bed Committee had drafted proposals for a seabed regime. These proposals reflected a desire for mineral price supports, transfers of technology from the industrialized countries to the developing nations, aid from developed countries to build oceanographic institutions, processing plants in developing countries and hiring preferences for people from developing countries. The Tanzanian draft, submitted to the Sea-bed Committee on March 24, 1971, suggested the treaty provide for "equitable sharing by States...taking into particular consideration the interests and needs of developing countries, whether landlocked or coastal."7 The second aim was that the authority would minimize fluctuations of prices of land minerals and raw materials taken from the seabed. Tanzania

6. Elliot Richardson, "Law of the Sea: A Reassessment of U.S. Interests," Mediterranean Quarterly, vol. 1, no. 2 (1990): p. 9.

7. Text of Tanzanian Draft can be found in Shigeru Oda, ed., The International Law of the Ocean Development: Basic Documents (Leyden; Sijthoff, 1972), p. 114. 
also wanted an International Seabed Authority to be empowered to explore and exploit the resources itself. The seabed authority would be in charge of mining and would oversee any subcontracting of the mining to private or national companies. 8 Tanzania also stressed that there should be formal exchanges of scientific and technical information as well as exchanges of scientists to assist with training.

Tanzania suggested the governance of the seabed be left to an assembly and council. The assembly would include every nation that was party to the treaty and each nation would have one vote; the council would consist of 18 members elected by the assembly, not less than three delegates from landlocked states. The representatives must be from different areas of the world to assure a geographic distribution. The council could be controlled by the lesser developed countries because they would control the assembly which elected the council.

Fourteen Latin American nations also submitted a proposal to the Sea-bed Committee in the summer of 1971.9 Like the Tanzanian proposal, it emphasized that the seabed should be exploited in a manner that minimized any fluctuation of prices for land-produced mineral exports. More specifically, it said the International Seabed Authority would have the power to control, reduce, suspend production or "fix" prices of minerals mined from the seabed. The Latin American proposal gave broad powers to the International Seabed Authority to

8. Ibid., p. 117.

9. Text of Latin American Draft can be found in Oda, ed., The International Law of Ocean Development: Basic Documents, p. 143. 
supervise all stages of scientific research in the common heritage area. The ISA would ensure "the participation of developing countries on terms of equality with developed countries in all aspects of the activities carried out in the area."10 Among these broad powers was the right of the authority to favor developing countries when siting processing plants and to "adopt appropriate measures to ensure the employment of qualified personnel from developing countries in all aspects of the activities carried out in the area." These were the affirmative action stipulations.

Some developing countries feared seabed mining would create a bonanza of minerals that might depress prices of their mineral exports. These fears, which proved unrealistic because seabed mining never developed, were based on the original estimated total volume of manganese nodules - some 1.5 trillion tons. However, the figure ignored market forces that would control production and the high cost of obtaining even a small fraction of these seabed minerals. ${ }^{11}$

The initial U.S. plan, called the Nixon proposal, for a seabed regime began with the statement that the seabed should be considered the common heritage of mankind.12 Article 5 of the proposal stated that an International Seabed Authority shall use revenues from exploration and exploitation of the mineral resources "for the benefit all mankind, particularly to promote the economic advancement of
10. Ibid., p. 144.
11. Richardson, Law of the Sea, p. 5.
12. Text of U.S. Proposal can be found in Juda, Ocean Space Rights, p. 205. 
developing States Parties to this Convention.."13 In this sense, Americans accepted the concept of the common heritage and Pardo's priorities without changes. According to Markus Schmidt, Elliot Richardson, the Under Secretary of State for President Richard M. Nixon, and David Packard, the Deputy Secretary of Defense, designed the American draft. ${ }^{14}$ During the 1970s, Richardson took other positions in the Nixon Administration, including Attorney General. He returned to the Law of the Sea process in 1977 as an appointee of another president, Jimmy Carter.

The American proposal submitted to the UN Sea-bed Committee in 1970 was explicit on geography and specific on economic and business concerns. The International Seabed Area was to begin just beyond the depth of 200 meters in the ocean. If the 200 -meter isobath was on the continental shelf, there would be a new area called the trusteeship zone between the 200-meter isobath and the end of the continental margin. The coastal state would manage the trusteeship zone, but would hold the zone in trust for the international community and would share revenues from resources with the international community. The international community would manage and reap the benefits of seabed resources beyond the trusteeship zone. The draft proposed an assembly, council and tribunal to govern the international seabed area. The council would have representatives of six of the most industrially-

13. Ibid.

14. Markus Schmidt, Common Heritage or Common Burden? (Oxford: Clarendon Press, 1989), p. 26. 
advanced nations that were engaged in seabed mining. The proposed council would also include 18 additional representatives, 12 would be from developing countries and at least two must represent land-locked or shelf-locked nations. ${ }^{15}$ The council was to draw up budgets and submit these for approval to the assembly. A tribunal would be created to resolve disputes, including disagreements over claims to ocean mining sites.

The proposed treaty included protection for mining companies that had already begun exploration and exploitation when the treaty was enacted. This was a concern of the newly developing American mineral-mining industry. 16 The treaty called for payments to the International Seabed Authority to be based on production and for there to be a rental fee for the seabed mining sites. This was similar to the American system of leasing outer continental shelf lands for oil and gas exploitation. The sites would be awarded to various exploiters using cash bonus bids, another similarity to the American oil and gas leasing program run by the Interior Department. The proposal, with its division of responsibilities for the trusteeship zones and the international seabed area, had familiar themes of balance of power found in the United States Constitution. In this case, the draft treaty was balancing the rights of the

15. These are the countries that because of their geography have no access to a continental shelf and therefore the resources of these rich oceanic areas. 16. U.S. Congress, House, Committee on International Relations, Report of Congressional Research Service on Deep Seabed Minerals: Resources, Diplomacy and Strategic Interest, 95th Cong., 2nd sess., 1 March 1978, p. 87. 
international government which was analogous to the federal government with the rights of the various coastal national governments which were analogous to the state governments. The national governments would have a version of "state's rights" in the trusteeship zone. They would be able to set up their own leasing policies and their own revenue garnering methods. However, they would have to donate some revenue to the larger international authority. The U.S. viewed the International Seabed Authority as a license board what would issue permits for various nations or private companies to explore and exploit the seabed, but not as a supranational institution that did the mining itself.

Comparing the proposals from the United States and the developing nations makes it easy to see what became the crucial disagreements in Committee I. Those disagreements were over whether the Seabed Authority should be a licensing body or a powerful international body that also ran seabed mining. Other disagreements centered on mandatory technology transfer, an idea American policy-makers found abhorrent, voting and representation in the assembly and council and payments to the International Seabed Authority. Yet, after nine years of negotiations, a draft was devised. It reflected a statement made early in the treaty process by the American negotiator, Leigh Ratiner, who called for a detailed mining regime. ${ }^{17}$ Ratiner pushed for detail on seabed mining because he feared that broad generalizations would be open to

17. U.N., L.O.S., (Doc. A/CONF. 62/C1/L6), 13 August 1974. 
interpretations favoring the developing countries that would have majority control of an assembly. The level of detail in the mining regime was overwhelming.

Negotiations moved slower in the Committee I than in any of the other two committees at UNCLOS for a number of reasons. The ideological split between developing countries and developed countries was the firmest in this committee. In the other two committees, the North-South split often fell apart when countries formed unusual alliances based on other issues such as geography. ${ }^{18}$ The seabed committee was also trying to design the world's first economic joint venture that would be run by an international organization. And seabed mining did not have the emotional immediacy that controlling existing pollution in the ocean had or that determining where fishermen could throw their nets has had throughout history. It was also not a top priority for the United States.

Another factor that slowed negotiations was declining interest in seabed minerals which occurred as the decade progressed and many people concluded they were not the treasure at the end of the rainbow. 19 In the course of the decade, scientists scaled back their initial estimates of the amount of seabed minerals. In addition, the fear of shortages of key minerals abated. The world also witnessed a rapid transformation of industry from one that was heavily

18. Bernard H. Oxman, "The Third United Nations Conference on the Law of the Sea: the 1976 New York Sessions," American Journal of International Law, vol. 71, no. 2 (1977): p. 251.

19. Marne Dubs, personal interview with author, Narragansett, RI, 23 July 1991. 
dependent on metals for machinery to one that depended more on information and soft computer technology. 20

By the mid-1970s, the developed nations and what is called the Group of 77 , the name given to developing nations that banded together to work as a voting group at international negotiations, were deadlocked over a seabed mining regime. The United States suggested a compromise in 1976 in an attempt to break the deadlock. On April 8, 1976, Secretary of State Henry Kissinger proposed what became known as the "parallel system." He suggested that the seabed regime have both American-style private-industry seabed mining and mining by the "Enterprise," the mining operation controlled by the International Seabed Authority. ${ }^{21}$

The compromise was a major concession for the United States; it was criticized by the American hard minerals industry and frowned upon by some members of Congress. By the mid-1970s, Congress had been working for nearly half a decade on national seabed mining legislation.22 Suspicious of the international negotiations on the common heritage concept, the small, but articulate leaders of the American hard minerals

20. John Padan, "Commercial Recovery of Deep Seabed Manganese Nodules: Twenty Years of Accomplishments," Marine Mining, vol. 9 (1990): p. 87-103.

21. Ann Hollick, U.S. Foreign Policy and the Law of the Sea, p. 316. Schmidt, Common Heritage or Common Burden?, p. 124. See also Senate Report No. 96-307. Deep Seabed Mineral Resources Act, 96th Cong., 1st sess., p. 86-88.

22. See, for example, U.S. Congress, Senate, Committee on Interior and Insular Affairs, Subcommittee on Minerals, Materials and Fuels, Mineral Resources of the Deep Seabed, 93rd Cong., 1st sess., 17 May 1973; and House, Committee on Foreign Affairs, Subcommittees on International Economic Policy and Trade and on International Organizations, The Deep Seabed Hard Mineral Resources Act, 96th Cong., 1 st sess., 11 July 1979. 
industry had turned to Congress for support. The industry which consisted of less than a dozen companies and consortiums that had done preliminary research since the early 1960s on deep seabed mining, promoted what it called interim national legislation. 23 Legislative supporters said they wanted Congress to adopt this legislation to encourage mining research and development to continue until an international treaty was completed to supersede the law.

The main reasons spokesmen for this small industry gave for interim legislation was that a treaty would take too long and American companies needed legal security to make multimillion dollar investments in mining research and exploration. The U.S. companies stressed that they needed long lead times before any actual mining could take place. And they wanted to hold onto the technological advantage they had over other countries in this new field.

In addition, the U.S. companies used Congress to express their specific desires for what an international regime should contain. They were skeptical of the common heritage concept and wanted the national law to stress that deep seabed mining could be done under the old concept of freedom of the high seas. The law that passed Congress in 1980, the Deep Seabed Hard Mineral Resources Act, states: "It is the legal opinion of the United States that exploration for and commercial recovery of hard mineral resources of the deep seabed are freedoms of the high seas subject to a duty of reasonable regard to the

23. Juda, Ocean Space Rights, pp. 130-135. 
interests of other states in their exercise of those other freedoms recognized by general principles of international law." 24 The legislation had to trumpet freedom of the seas because it is the legal doctrine that allows one nation to take resources from an unowned area of the sea.

The law does not endorse the concept of the common heritage. Instead, it pays symbolic homage or lip service to the phrase and advocates a number of principles that are inimical to the concept as was defined by Pardo. The law states that the United States support of the 1970 United Nations Declaration of Principles was not an acceptance of the common heritage concept. Instead, the United States supported the resolution with the understanding that the concept would be clearly defined in a treaty. The Deep Seabed Hard Mineral Resources Act states that the United States is not bound by the 1970 principles because no treaty had defined the common heritage to the satisfaction of the United States. 25

It took the mining industry and the small group of Congressional supporters nine years to see a law passed. The law that was passed was quite different from the original industry proposal which would have guaranteed the federal government bail out any private company that lost money because of changes in the regime due to an international treaty. Presidents Nixon and Ford opposed a national seabed mining law primarily because they wanted to give UNCLOS a chance to

24. U.S. Code, Deep Seabed Hard Mineral Resources Act, Public Law 96-283, 28 June 1980.

25. Ibid., Title I, Sec. 2, no. 7. 
devise an international treaty. However, President Carter initially opposed the law, but decided in 1978 to endorse it. 26 President Carter and Elliot Richardson, Carter's ambassador-atlarge and special representative for the Law of the Sea, endorsed the legislation with the hope that it would put pressure on the international treaty negotiations to bring them to a close. Carter and Richardson endorsed national legislation at a point in the UNCLOS negotiations when the United States had achieved its primary goals of addressing navigational and environmental concerns. Richardson said in 1992: "I did not believe the seabed bill was worth a damn then and I do not believe it now. We thought at the time its passage would strengthen our bargaining position." 27

However, the developing countries that had formed an organization called the Group of 77 strongly objected to American legislation and its stipulation that other mining nations could join a reciprocating agreement to form a small, select treaty agreement outside UNCLOS to divide up portions of the seabed.28 Satya Nandan, a spokesman for the Group of 77, submitted a statement to Congress strongly opposing the bill and claiming it violated The Declaration for a Moratorium on Seabed Exploration and Exploitation, the 1969 resolution passed by the United Nations General Assembly which placed a

26. Schmidt, Common Heritage or Common Burden?, p. 87.

27. Richardson interview, 7 May 1992.

28. U.S. Code, Deep Seabed Hard Mineral Resources Act, Title I, Sec. 118. 
moratorium on exploitation of the seabed by any nation until an international regime was established.29

Richardson, a Republican who served as Attorney General for Nixon until his celebrated resignation during Watergate, played a key role in UNCLOS. He served as the top American negotiator from 1977 to 1980. He took the position because of a deep commitment to the ocean that dated back to his childhood when he would fish off the coast of Marblehead, Massachusetts, with his father and send a log of the species of fish he found to his uncle, Henry B. Bigelow, the first director of the Woods Hole Oceanographic Institution. Richardson made ocean issues a priority throughout his career, prosecuting illegal fishing while U.S. Attorney in Boston during the 1950s, promoting legislation to fund ocean research while an aide to Sen. Leverett Saltonstall, R-Massachusetts, and helping to push for a major Law of the Sea conference in the late 1960s while working for the Nixon administration. In fact, Richardson went against the advice of fellow Republicans by accepting the position as Law of the Sea negotiator in 1977 for a Democratic president. He recalled in a 1992 interview that his former Deputy Secretary of Defense, William Clemens, who became governor of Texas, questioned why he would take the Law of the Sea negotiator position. Richardson responded: "I said, 'Bill, you may think

29. For Nandan's statement see U.S. Senate, Committee on Foreign Relations, Subcommittee on Arms Control, Oceans and International Environment, Hearing on the Deep Seabed Hard Mineral Resources Act, 95th Cong., 2nd Sess., 17 August 1978, p. 243. 
Texas is half the world, but I'm dealing with the problems of two thirds of the earth." 30

Richardson came to the negotiations with his own ideas about the common heritage concept and how it should be codified. He viewed the concept as it had been articulated by Lyndon Johnson at the christening of the Oceanographer in 1966. "I thought it would make no sense to allow a competitive struggle to divide up the seabed. It was a global commons to be shared. I've never believed the concept meant any more than that. To me, nothing in the concept foreshadowed the elaborate structure of the International Seabed Authority." For Richardson, the practical way to manage the common heritage was 1) no individual state would be allowed to acquire title to the seabed 2) exploitation should be done in a way that contributes to the common interest of mankind 3 ) there should be a fair means of sharing the proceeds from mining among nations 4) there should be a fair and efficient way of determining who should mine. Checks should be made of technical capability, environmental safety and financial resources of any prospective miner and 5) there should be a body that administers contracts and collects proceeds. Said Richardson: "The idea of superimposing a parastatal organization has always been a nutty idea." 31

Richardson blamed the proposed organization of the International Seabed Authority which was well in place by the

30. Richardson interview, 7 May 1992

31.Ibid. 
time he joined the negotiations in 1977 on promoters of the New International Economic Order. He said at one point that linking the NIEO and the common heritage idea emasculated the common heritage. 32

Despite these opinions, Richardson was primarily concerned with creating a treaty and he was willing to make concessions to the developing countries in the seabed committee to get a viable package deal. By the mid 1970s, the major issues in the two other committees had been resolved and Richardson focused on the seabed ideological deadlock. 33

While Richardson attempted to negotiate a settlement, the mainstream press in America and the U.S. Congress became increasingly critical of the common heritage concept. Many critics suggested that it smacked of socialism, a dirty word in the United States. Robert A. Goldwin, a political advisor and former director of Constitutional Studies at the American Enterprise Institute, strongly criticized the common heritage concept in Commentary, a neo-conservative publication. He observed that various nations came to the convention with the attitude that the common heritage meant joint ownership and that each country was a stockholder. Goldwin argued that this concept went against Lockean individualism, the type of individualism that he said was deeply ingrained in American political and economic tradition. According to Goldwin's view of

32. Schmidt, Common Heritage of Common Burden?, p. 109.

33. Bemard H. Oxman, "The Third United Nations Conference on the Law of the Sea: the 1977 New York Session," American Journal of International Law, vol. 72, no. 1 (1978). 
American capitalism, it is best to encourage private enterprise to use natural resources with as little regulation as possible. In turn, private enterprise will create benefits for the good of the entire society. This belief was exactly the opposite of what Pardo was saying in his speech, Goldwin concluded. He claimed that Pardo warned that strong nations and private companies would dominate seabed resources to the detriment of the world unless there was some international regime overseeing the exploration and exploitation of the deep sea. ${ }^{34}$ Goldwin also condemned the proposed seabed regime that had been negotiated at the conference by 1981 as a "complicated, highly organized, un-elected, powerful government with abundant funding that can not be controlled or cut off." He concluded quite simplistically that free enterprise and freedom of the seas would better serve society. 35

By the end of the 1970 s, pundits in the mainstream press also criticized the Law of the Sea negotiations on the common heritage of mankind. New York Times columnist William Safire blasted seabed negotiations calling them "history's greatest attempted rip off." $\mathrm{He}$ described the draft convention as a "plan to place ownership in a new bureaucracy...dominated by the dictators of the undeveloped world." He charged that three presidents had been sailing on the "good ship Guilty Conscience" and were making an "unnecessary compromise of

34. Robert Goldwin, "Locke and the Law of the Sea," Commentary, vol. 71, no. 6 (June 1981): p. 49.

35. Ibid., p. 50. 
our basic free market principles."36 The Washington Post editorial writers accused "Third Worlders" and "Land-based producers of minerals" of seeking to restrict competition from seabed mining. 37 The growing discontent with the seabed negotiations provided a backdrop for President Reagan's 1981 denouncement of the section of the treaty that established a seabed mining regime.

Richardson stepped down as ambassador in 1980 for professional reasons. He said he was aware there was an election approaching and he wanted to reestablish his Republican credentials. When he stepped down, he said he felt confident that the treaty was nearly ready for signing and he said he naively believed it would be signed by the United States. "Had Carter been re-elected, the treaty would have been signed," he maintained. 38

However, Ronald Reagan was elected president and took office in January 1981. The Senate also came under Republican control. On March 2, the State Department issued a statement that it would ask the U.S. representative at UNCLOS to be sure the negotiations did not end in the spring session until there was a policy review. "The interested Departments and Agencies have begun studies of the serious problems raised by the Draft Convention..."39 In April, Reagan's newly appointed

36. William Safire, "Very Deep Thoughts," New York Times, 4 July 1977, p. 17.

37. "American Seabed Mining," Washington Post, 19 July 1978, p. A 14.

38. Richardson interview, 7 May 1992.

39. Bernard H. Oxman, "The Third United Nations Conference on the Law of the Sea:

the Tenth Session," American Journal of International Law, vol. 76 (1982): p. 2. 
ambassador to UNCLOS, James Malone, told Congress that there were provisions in the treaty that were upsetting to industry, Congress and the American public and that were in conflict with the goals of the Reagan administration. 40

The American actions in the eleventh hour upset the developing countries and some developed countries. The Soviets criticized the Americans for trying to undo a decade of work by more than 150 countries and charged it was bad faith negotiation. 41 The leader of the Group of 77, Inam Ul-Haque of Pakistan said: "There have been scores of changes in regimes in different countries since the work on the treaty was started but no new regime had so far disowned what its predecessors had striven to achieve in the field of international cooperation for the exploitation of the resources of the seabed which have been universally recognized as being the common heritage of mankind." 42

Malone stated his objections to the negotiated seabed regime in an August 5, 1981 statement to UNCLOS. Although he objected to a number of details of the seabed mining regime, the overall objection was that the regime went directly against the Reagan philosophy of least government. "Our government is embarked on a course of action designed to reduce inflation and stimulate productivity. It is also attempting to reduce burdensome regulations that impede industrial activity. Many

40. Malone testimony quoted by Oxman on page 3 of his review of the Tenth Session, see note 39.

41. Ibid., p. 5

42. Ibid., p. 6. 
have viewed the Draft Convention as being inconsistent with these basic goals." 43 Malone objected to what he called discriminatory advantages given to the "Enterprise," the internationally controlled mining operation, that would be funded by the international community and would mine a site parallel to a site mined by any private company or national mining operation. He objected to the transfer of technology stipulations in the treaty, the limits on production that were established for nickel, to the fact that no seat on the Council was guaranteed to the United States and that there was a 20year review provision that could alter the entire regime by a vote the United States could not control.44

Elliot Richardson, although no longer part of UNCLOS negotiations, spoke before Congress to object to the content of Malone's statements. He said that the treaty provisions for membership on the council allow for Western industrialized nations to have 6-9 seats. "The United States, either as probably the largest investor in deep seabed mining or as the largest importer or consumer of deep seabed minerals would have as much practical assurance of being named to one of these groups ..." Richardson testified before the House Foreign Affairs Committee. $45 \mathrm{He}$ also pointed out that the treaty said

43. Myron H. Nordquist and Choon-ho Park, eds., Reports of the United States Delegation to the Third United Nations Conference on the Law of the Sea. Occasional Paper No. 33 (Honolulu: The Law of the Sea Institute, University of Hawaii, 1983), p. 528.

44. Oxman, Tenth Session, p. 9.

45. For text of Richardson speech see U.S. Congress, House, Foreign Affairs Committee, U.S. Policy and the Third U.N. Conference on the Law of the Sea, 97th Cong., 1st sess., 14 May, 1981, pp. 27-51. 
that technology transfer would occur with adequate compensation. He noted that a number of companies have already offered to sell technology to the Enterprise.

The Reagan administration decided that it would not accept Part XI - the seabed portion of the treaty - unless major changes were made. But the other nations, many disgusted with the United States for its last minute demands, decided to adopt the treaty with or without U.S. support.46 So when the signing ceremony was held in 1982, the United States refused to sign and remains today the leading developed nation boycotting the treaty. It has also urged a number of other developed nations to withhold ratification of the treaty because of the seabed regime. U.S. Ambassador Thomas Clingan announced at the treaty signing ceremony in Montego Bay, Jamaica that the U.S. viewed the parts of the convention dealing with navigation, overflight, the exclusive economic zone, innocent passage and the territorial sea as part of "prevailing international practice," however the United States could not accept the seabed portions. 47

A total of 117 nations signed the final act and to date there have been 51 ratifications. The treaty will go into effect one year after the 60 th ratification signature is deposited.48

46. Oxman, Tenth Session, p. 21. The vote on the convention on 30 April 1982 was 130-4, with 17 abstentions. See The 1982 U.N. Convention on the Law of the Sea in I.L.M. vol. XXI, no. 6, November 1982.

47. Nordquist and Park, Reports of the United States Delegation, p. 665.

48. The 1982 U.N. Conv. on the L.O.S., Part XVII, Articles 305-308. 
The countries that have ratified the treaty are predominantly the developing countries of the world

The seabed regime in the final treaty was a mixture of elements from proposals by the United States and Third World nations. However, as with each of the early proposals, the statement about the common heritage of mankind remained largely unchanged from the 1970 Declaration of Principles. The international seabed area and its resources were to be the common heritage of mankind. 49 It was defined as the area beyond the limits of national jurisdiction - that is beyond the exclusive economic zone and/or the continental shelf.

Other components of the common heritage of mankind expressed by Pardo in 1967 were present in the treaty. Article 137 stated that no state could claim sovereignty over the area or the resources. The article went further to state that all rights to the resources were "vested in mankind as a whole, on whose behalf the Authority shall act."50 Article 140 states that there will be preferences. The regime should take "into particular consideration the interests and needs of the developing States and of peoples who have not attained full independence or other self-governing status..." 51 The regime also promoted cooperation in marine scientific research and assistance to developing countries to strengthen research activities and transfer technology.52 The United States and other developed
49. Ibid., Art. 136.
50. Ibid., Art. 137, no. 2.
51. Ibid., Art 140, no. 1.
52. Ibid., Art. 143. 
nations influenced the wording of the technology transfer sections to ensure that transfers were not required, nor free.

They were encouraged at fair market rates. 53

The seabed section also created the International Seabed Authority which would grant contracts for seabed mining. One of the major economic compromises between countries that promoted free-market economics and those that favored planned economies was the creation of the parallel mining system. Instead of adopting the idea promoted by the developing countries that the International Seabed Authority should run the mining operations exclusively, or adopting the developed-nation view that there should be a relatively weak licensing board to regulate private mining companies, the treaty said there would be both. Whenever a private company wanted to mine a site, the company would have to propose two sites, one to be awarded to the company and the other to be reserved for the Enterprise to mine.54

The treaty's Article 150 declared that there would be some assistance given to countries in which seabed mining had a negative effect on a mineral-export national economy. Article 151 explains that there will be a ceiling on nickel production. Because nickel is one of the four major components of manganese nodules, a ceiling on it established automatic ceilings on the other minerals which exist in relatively consistent proportions in the nodules. The treaty describes

53. Ibid., Annex III, Art. 5, no. 3, a.

54. Ibid., Annex III, Art. 8. 
specifically how this ceiling will be set and it says there will be a way of compensating developing countries that are adversely affected by the ceiling. 55

The treaty established a Preparatory Commission that would include all signatories to the convention. There are currently 159 nations that have signed. This group works together using consensus negotiations to draft provisional deep seabed mining regulations. 56 Over the last nine years, the Preparatory Commission has resolved a number of issues, but has yet to resolve the hard-core issues such as how to compensate land-based mineral producers, how to include observers that are not members of the treaty and whether decisions will be made by vote or consensus. 57

The commission's most important accomplishment is that it has registered the Soviet Union, Japan, France, India, China and a group of former Eastern European nations as "pioneer investors." 58 This means that these countries or consortiums operating in these countries have received a portion of the international deep seabed for exploration and exploitation. This was no simple feat. It required extensive negotiations to resolve overlapping claims in the Pacific Ocean area called the Clarion-Clipperton Zone. Scientific studies have pointed a

55. Ibid., Art. 151 , no. 4.

56. Ibid., Annex I.

57. Council on Ocean Law, Oceans Policy News, vol. ix, no. 3 (March 1992): p. 1-2. 58. Moritaka Hayashi, "Registration of the First Group of Pioneer Investors by the Preparatory Commission for the International Sea-Bed Authority and for the International Tribunal for the Law of the Sea," Ocean Development and International Law, vol. 20, (1989): p. 1-33. 
substantial volume of manganese nodules with high concentrations of nickel and cobalt in this area of the Pacific.59 The Preparatory Commission has also succeeded in resolving overlapping seabed claims with mining consortiums from three industrialized nations that have refused to sign the treaty because of the seabed regime. 60 These consortiums are registered for seabed mining in their respective countries under national legislation that was passed in the early 1980s following the the American Deep Seabed Hard Mineral Resources Act. They include consortiums registered in the United States, the United Kingdom and Germany. There was a point in Preparatory Commission negotiations when the spokesmen from both the lesser developed countries and the Soviet Union condemned as illegal these outside mining laws and registrants. However, in the late 1980s, Preparatory Commission members decided that encouraging an international regime was more important than fueling a standoff between competing regimes so the commission took steps to resolve overlapping claims. The hope is that these industrialized countries will eventually join the treaty. The Third World countries that dominate the commission also recognize that the industrialized countries will be significant financial contributors, technological and scientific advisors to the international seabed regime and the Enterprise operation.

59. Padan, Commercial Recovery, pp. 98-99.

60. Hayaski, Registration of the First Group of Pioneer Investors, p. 23. 
Another trend in the Preparatory Commission has been a softening of the ideological line that dominated UNCLOS; there have been expressions by Third World leaders that the market economy approach is not as abhorrent as it was perceived in the 1970s. An example of the softening is the resolution of overlapping seabed claims. Preparatory Commission ensured that the International Seabed Authority had a prime mining site in the center of the Clarion-Clipperton Zone. However it did not always require each pioneer investor to present a site of equal size to the one it wanted to explore. This was a softening of the rigid site-for-site parallel system in the convention.61

A conciliatory effort is apparent in a statement by Ambassador Jose Luis Jesus of Cape Verde, chairman of the Preparatory Commission, to the United Nations General Assembly on December 10, 1991. He said:

"the problems that we face today in part XI were born out of assumptions made in past negotiations that have proved, only 10 years later, to be at odds with today's realities. We should therefore learn the lesson and exercise restraint in attempting to find solutions today for the seabed mining system on the basis of assumptions that might most likely prove to be in contradiction with the facts and realities of tomorrow's world." 62

The UN resolution that Jesus put forward said "the Assembly would recognize that political and economic changes, including particularly a growing reliance on market principles, underscored the need to re-evaluate, in light of the issues of

61. Ibid., p. 15.

62. Council on Ocean Law, Oceans Policy News, vol. ix, no. 1 (January 1992): p. 2. 
concern to some states, matters in the regime to be applied to the Area and its resources and that a productive dialogue on such issues involving all interested parties would facilitate the prospect of universal participation in the Convention, for the benefit of mankind as a whole." 63

Former UN Secretary-General Perez de Cuellar began an effort in 1990 to resolve problems in the seabed regime. These informal talks involve Preparatory Commission members and industrialized nations. They are continuing under the new Secretary-General, Boutros Ghali, who was instrumental in urging his country, Egypt, to ratify UNCLOS.64 There is hope that a resolution will be made and there is a strong likelihood that nine more nations will ratify the treaty in the upcoming years, bringing it into force. The United States, however, may still be reluctant to ratify the treaty unless some major changes are made to the seabed regime, or an election brings a new president with a different perspective than that taken in the last decade by Presidents Reagan and Bush.

Although the U.S. rejection of the seabed mining regime had a negative effect on the common heritage concept, it was the economics of mineral mining that dealt the most serious blow to seabed mining in the 1980 s. While mineral shortages and Third World mineral cartels were feared in the early 1970s a quite different situation occurred in the 1980s. In 1984, Marne Dubs, manager of Kennecott Consortium's

63. Ibid., 2-3

64. Dolliver Nelson, Executive Secretary of Preparatory Commission, Law of the Sea Office for the U.N. Secretariat, telephone interview with author, 20 May 1992. 
manganese nodule project throughout the 1970s, pronounced that "commercial interest in seabed resources is close to its nadir." Even the land-based mines that produced these metals at much lower costs than would be possible in a seabed operation were suffering. The economic forecast has been that metal prices will "languish for the rest of the century and well into the 21 st century. 65

It was also clear by the end of the 1970s that Americans were not committed to the same common heritage concept as the developing nations. In a speech before the Washington Press Club on March 14, 1979, Elliott Richardson said, "We are convinced that nations retain their rights to mine the deep oceans as one of the freedoms of the seas." 66 What Richardson said in 1979 was the opposite of what President Johnson had said in the 1966 speech in which he called ocean wealth the "legacy of all mankind" and warned against its being taken only by the wealthy nations. But President Johnson had never been asked to shift from the broad philosophical idea of a common heritage of mankind to the specifics of establishing an internationally controlled business that could satisfy diametrically opposed economic philosophies.

Under the demanding policy-making arena, the common heritage concept unravelled. The United States could embrace the broad concept of a global commons, but could not accept a

65. Marne Dubs, "Minerals of the Deep Sea: Myth and Reality," In Giulio Pontecorvo, ed., The New Order of The Oceans (New York: Columbia University Press, 1986), p. 89.

66. Department of State Bulletin, no. 60, 14 March 1979. 
highly complex government that would oversee three-quarters of the earth, regulate and run a mining industry in this area. Third World nations also were selective in which components of Pardo's concept they embraced. They infused the concept with their own desires for price controls, technology transfers and fees on private industry engaged in mining. They wanted too place the financial burden on mining nations for funding for the internationally run mining operation - the Enterprise.

The concept also suffered during the 1970s as the deep ocean faded from a relatively high position on the foreign policy agenda. Other domestic and foreign policy concerns including the Vietnam War, the oil embargo and the Iranian hostage crisis took its place. President Jimmy Carter did not view ocean policy as an important form of international relations as did Presidents Johnson or Nixon.67 And President Reagan saw no need to make any concessions on seabed mining to the Third World.

The United Nations and Third World leaders continued to support the seabed regime and have been willing in recent years to make compromises with industrialized nations to resolve disputes on overlapping seabed mining sites for the future. To date, these efforts have not convinced the United States to sign the treaty or to participate, even as an observer, at the Preparatory Commission meetings. These meetings are

67. Richardson interview, 7 May 1992. See also L. King and F. Jennings, "The Executive and the Oceans: Three Decades of United States Marine Policy," Marine Technology Society Journal, vol. 22, (1988): p. 17-32. 
the place where the United States could push for changes to the seabed regime. The other forum for reconciliation is a series of informal meetings launched by the UN SecretaryGeneral. There have been no major breakthroughs at these meetings, but U.S. participation continues. There is some hope a resolution will be made here. 


\section{Conclusion}

In 1983, Arvid Pardo declared "...the common heritage regime established for the international seabed is little short of a disaster."1 But nearly 10 years later, Elizabeth Mann Borgese believes the regime is the most advanced form of governance ever created by man. From her home in Halifax, Nova Scotia, she is still working to get the required 60 nations to ratify the treaty. ${ }^{2}$ To date, 51 nations have ratified or acceded to the treaty. They are predominantly small or developing nations. The only industrial nation to ratify the treaty is Iceland. 3 The larger industrial nations that once controlled international ocean law, including many of the nations capable of mining the deep seabed, have refused to ratify the treaty because of the seabed mining regime.

The concept of the common heritage as defined by Arvid Pardo in 1967 was vague and open to a multitude of interpretations. That was part of its beauty as a rallying slogan for a diverse group of advocates and nations. But it was also its downfall as a concrete framework for an economic endeavor such as mining. The people who rallied for the common heritage were unsuccessful in turning the philosophy into a

1. Arvid Pardo, "The Convention on the Law of the Sea: a Preliminary Appraisal," San Diego Law Review, vol. 20, no. 2 (April 1983): p. 499.

2. Elisabeth Mann Borgese, personal interview with author, Halifax, Canada, 1 November 1991.

3. Council on Ocean Law, Oceans Policy News, vol. ix, no. 1 (January 1992): p. 4. 
viable economic system. The advocates were good at saying that the new concept was neither sovereignty nor freedom of the seas, neither capitalism nor socialism, but they were unable to clearly define what it was. It is an idea much closer to socialism because it involves common property. This was one of the main reasons it was never embraced fully by policymakers and leaders of the United States - a nation that was founded on the sanctity of private property.

The common heritage was an idea born at the right time, but one that matured in a more difficult political environment. Pardo, President Lyndon Johnson and Borgese began speaking about a common heritage in the oceans at a time in the late 1960s when the world was searching for answers to global problems of inequality and poverty. It was also a time when people were willing to strongly criticize the capitalistic economies of the developed world. But as the idea moved into the policy-making arena in the 1970s, it became the job of more practically-minded people to create a common heritage regime.

Many of the delegates to UNCLOS, unlike Pardo and Borgese, had national, not necessarily international interests at heart. They were realists not idealists. The delegates from Third World nations developed and embraced the highlynationalistic concept of a 200-mile exclusive economic zone an extension of national territory into what had been the high seas. They also wanted a deep seabed regime that brought the poorer nations as much financial, technological and legal 
benefits as possible and the least amount of disruption to any mineral export income they had. And they liked the idea of creating a new form of international law with their stamp on it.

The delegates from the United States did not have the same desire to create a new order of the oceans as their counterparts from the Third World. Elliot Richardson, the U.S. Ambassador to the Law of the Sea conference from 1977 to 1980, was much more concerned with getting a treaty in place that satisfied a range of American concerns including the desire to stop creeping jurisdiction by the world's new nations. He viewed the seabed regime with its benefits for the Third World as part of the "package deal" established at the beginning of UNCLOS. The developed nations would ask for cooperation from the Third World on navigation and environmental issues that were important to them. In return, the developed nations would give the developing countries benefits such as a share of seabed wealth, technology transfers, regional oceanographic centers and participation in a new international mining organization.

Although Richardson was willing to make this bargain and was willing to accept a number of demands from the Third World, President Reagan was ultimately unwilling to make such a bargain. It is doubtful that the Republican-controlled U.S. Senate with its responsibility for approving international treaties would have consented to such a bargain either. In a decade, the type of idealism that marked the Johnson administration's war on poverty and Food for Peace program 
had evaporated. The 1970s had been difficult years for Americans and the years had taxed the nation's sympathy for international solutions that depended in U.S. generosity. The Vietnam War, the OPEC oil embargo and the Iranian Hostage Crisis helped to rob Americans of international idealism and sympathy for the Third World. The 1990s have seen no reversal of this trend. There is no economic or political need today to court the Third World by making concessions such as accepting what is viewed as a socialistic seabed mining regime. ${ }^{4}$

The problem of designing an economic enterprise that satisfies countries that believe in the free market and those that feel disadvantaged in the free market and advocate more government control, is a task on the agenda of future international treaty negotiations. Future negotiations will be affected by recent historic developments that call into question the state-controlled economy and highlight some advantages of the market-approach. The fall of communism and statecontrolled economies in Eastern Europe will contribute to changes in the attitude of some of the Third World nations that vehemently pushed for a powerful government-controlled seabed authority. There is already evidence at the Law of the Sea Preparatory Commission that Third World leaders are softening their stance on demands that the Enterprise be given exactly the same size seabed area for mining as any private or

4. Jane Perlez, "Stranded by Superpowers, Africa Seeks an Identity," New York Times (May 17, 1992), p. 1. 
national mining operation. The New International Economic Order is no longer the battle cry. If the conference on the Law of the Sea were held today, an entirely different common heritage regime for the seabed might be written based on the recent criticism of interventionist state economic policies, the high cost of mining, the decreased world demand for these minerals and the increased environmental concern for the deep ocean.

Americans are recognizing these changes. A number of marine policy leaders including Elliot Richardson, Marne Dubs and Senator Claiborne Pell have urged the resolution of these differences and the ratification of a universal Law of the Sea treaty. Elliot Richardson pointed out in 1990 that the developing countries were now more willing to make compromises with developed countries. He said: "Even among the Group of 77 the NIEO no longer has many true believers, and the Enterprise has lost much of its mystique." Richardson urged the U.S. to stop its boycott of Preparatory Commission talks. "It should want to take advantage of any opportunity to correct the defects of Part XI. While Part XI is not nearly as bad as the Reagan administration made it out to be, it can and should be significantly improved."5 Richardson believes that seabed mining will eventually take place even if it is not the great bonanza that was predicted.

5. Elliot Richardson, "Law of the Sea: A Reassessment of U.S. Interests," Mediterranean Quarterly, vol. 1, no. 2 (1990): p. 10. 
Richardson is not alone in supporting an international regime for seabed mining. Even some mining industry officials who lobbied in Congress for national seabed mining legislation have softened their criticism of the 1982 United Nations Convention on the Law of the Sea seabed regime and have reconsidered their support of national regulation. Marne Dubs, formerly Kennecott Consortium's manganese nodule project manager, stated in 1984 that he and other industry spokesmen promoted a myth that technology transfer was a pariah to American seabed mining companies who wanted to protect their competitive commercial advantage. Dubs said the reality was that seabed investors have "little or nothing worth protecting and even any marginal value is rapidly disappearing with the passage of time." He explained that the technology for seabed mining was not top secret and much of it was adapted from offshore oil drilling technology. 6

Dubs also said it was a myth that the seabed provisions would prohibit private enterprise from investing in mining. $\mathrm{He}$ said the reality is that rules and regulations could be developed by the Preparatory Commission to satisfy private investment. Dubs concluded that the first ocean mining that will occur will be government subsidized because the expense is too much for private enterprise to take on. ${ }^{7} \mathrm{He}$ suggested it was an American myth promoted in the 1970 s that pure private

6. Marne Dubs, "Minerals of the Deep Sea: Myth and Reality," In Giulio Pontecorvo, ed., The New Order of the Oceans (New York: Columbia University Press, 1986), p. 102.

7. Ibid., p. 121. 
enterprise was the best and only way to see the riches of seabed exploited for the betterment to mankind.

Senator Claiborne Pell has continually urged the United States to stop boycotting the Preparatory Commission and attend as an observer with the goal of resolving differences and eventually signing the treaty. "We must take off our ideological cloaks," Pell said in a 1991 interview. ${ }^{8}$ I also believe this is what the United States should do.

Despite the failure of the seabed regime to translate into mining and tangible benefits for the lesser developed countries, there were successes in the common heritage movement. The primary success was that the idea of a shared resource that belongs to mankind as a whole is now a permanent concept in international law and marine policy. Its repetition in United Nations resolutions, its definition in the Law of the Sea Treaty and its association with a clearly defined geographic area - the deep seabed beyond national jurisdiction all led to making it a part of marine law and geography.

The common heritage concept also gave a new field marine affairs - a central idea to examine and rally behind. It excited a small, but fervent group of nongovernmental organizations that tried to influence international marine policy. Today nongovernmental organizations are thriving and raising their voices at other international negotiations, some marine-related, others related to broader environmental concerns. They are a vital force that will only increase as

8. Sen. Claiborne Pell, telephone interview with author, 2 December 1991. 
environmental problems become more real to the general public and as the wealth gap between rich and poor nations, and between rich and poor peoples within nations, continues to threaten international and national stability.

The common heritage movement is also an example of how successful a small group of people can be in promoting an idealistic international legal concept. The idea, although initially supported by the United States government, was most strongly and clearly articulated by Arvid Pardo, an Ambassador from Malta. It drew a handful of advocates from the United States and a small group of scholarly advocates in Europe. A number of governmental leaders and statesmen from the Third World were spokesmen for the concept. The common heritage idea was one of the main reasons the United Nations convened the world's largest Law of the Sea conference. Devising a regime for the common heritage area of the deep seabed was the only reason negotiations lagged beyond the mid-1970s. This is evidence that the idea challenged people. It is also evidence that the idea had something in it to satisfy different political philosophies. The lengthy negotiations also reflected the fact that the idea was to be used to regulate a large area of earth that is little understood. The idea tapped into a belief in the importance of establishing places on earth that are not owned by nations and are protected for the future. Many societies have recognized the morality of sharing the earth's natural resources in an equitable manner. But the actual practice of international resource management remains in its infancy. 
The success of the common heritage movement in making the idea a permanent part of philosophy suggests that a larger, more powerful constituency for the oceans might promote similar ideas. In recent years, the constituency for the oceans has grown, but not as a constituency focused on the deep sea. Instead, the growth has been among the numbers of advocates for coastal area issues such as pollution cleanup, fish and mammal conservation. In the United States, attention shifted from the deep seabed and its wealth to the coastal zone in the 1970s. The problems of pollution, human health and overfishing were much more immediate than a mining proposition for the deep seabed. Just as the more immediate concept of the exclusive economic zone became one of the most significant changes negotiated at UNCLOS and broadly accepted by the world, the more tangible coastal issues draw a constituency that deep ocean issues have yet to attract. The reason is that people need to feel connected to what they are discussing and promoting. It was always difficult for people to feel connected to the remote and dark seabed. It took idealists such as Borgese to grasp the abstract idea that a regime for the deep seabed was a worthy cause to spend one's life trying to achieve.

There are two distinct views on whether the principle of the common heritage of mankind is a part of international law. A number of developing nations argued that the principle was a part of law. The representative from Trinidad and Tobago at UNCLOS said "the principle of the common heritage of mankind is not new law, it is not constitutive but rather declaratory of 
existing law."9 But legal scholars from the west such as

Christopher Joyner countered that the common heritage of mankind principle did not meet the requirements of customary or conventional international law because first of all the treaty has yet to be ratified by enough countries to bring it into force. Moreover, the principle also failed to meet criteria as customary law. He said it had not become part of state practice. Instead, Joyner concluded the principle was part of philosophy; it was "a conceptual ideal not an international legal reality supported by state practice." 10

Joyner is right that the common heritage is currently part of international legal philosophy. It will become international conventional law if nine more countries ratify the treaty. This may mean that the industrialized countries that have national legislation regulating seabed mining will be violating international law. This should be a concern of the United States, Germany and the United Kingdom - three of the countries that have refused to sign or ratify the treaty and have adopted national legislation. The U.S. legislation is called an interim law and is supposed to be superseded by an international treaty that is accepted by the U.S. However, there is a section of the law entitled "Transition to International Agreement" which

9. Milan Bulajic, Principles of International Development Law (Boston: Martinus Nijhoff Publishers, 1986), p. 311.

10. Christopher C. Joyner, "Legal Implications of the Concept of The Common Heritage of Mankind," International and Comparative Law Quarterly, vol. 35 (1986): p. 73. See also Paul L. Saffo, "The Common Heritage of Mankind: Has the General Assembly Created a Law to Govern Seabed Mining?" Tulane Law Review, vol. 53 (1979): p. 492-520. 
includes a list of what Congress demands the international agreement contain. The most important item on the list is that the international treaty is not to "impose significant new economic burdens upon such citizens with respect to such operations with the effect of preventing the continuation of such operations on a viable economic basis."11 As the treaty stands today, it would impose additional fees on an American miner that the U.S. law does not require.

Applying the concept of the common heritage of mankind to the deep seabed was a vehicle for Pardo and Borgese. They needed a place to give birth to their concept of cooperative international relations. The developing countries that promoted the concept of the common heritage wanted to make it a piece of a New International Economic Order. American diplomats went to UNCLOS resolved to curb creeping jurisdiction and maintain navigational freedom. They viewed the common heritage as a way to halt unilateral claims on increasingly larger areas of the ocean. They also viewed it as a bargaining chip to use with Third World nations. Americans benefited from the effect the common heritage concept had on preserving the deep seabed from creeping national claims. Yet Americans also passed unilateral legislation giving American miners the right to make unilateral claims to mine the deep seabed. American policy-makers wanted it both ways. This conflict is an embarrassment to the United States. However, President

11. U.S. Code, Deep Seabed Hard Mineral Resources Act, Public Law 96-283, Title II, June 28, 1980. 
George Bush and his predecessor, Ronald Reagan, have refused to acknowledge this hypocritical position. Both presidents, prior to taking office, had voiced strong opposition to the concept of the common heritage. It is unlikely the conflict will be resolved in the near future. It may only be resolved when it becomes practical or economical for the United States to join the international agreement. This may only occur if mining is viewed as economically viable or necessary.

Although the common heritage of mankind concept is not yet part of international ocean law, the concept has become part of international space law. The common heritage of mankind is a central component of the "Agreement Governing the Activities of States on the Moon and Other Celestial Bodies," a treaty finalized in 1979. Article $\mathrm{X}$, paragraph I states that: "The moon and its natural resources are the common heritage of mankind." Echoing Pardo's delineation of the concept of the common heritage, the moon treaty states that the moon and its natural resources shall not be "subject to national appropriation by any claim of sovereignty.." The treaty also ensures freedom of scientific investigation and that the moon and its resources will be used for "the betterment of all peoples, not just for those who possess the technological wherewithal to exploit them." 12

12. Space Treaty quoted in Joyner, p. 197. See also Peter D. Nesgos, "The Proposed International Sea-Bed Authority as a Model for the Future Outer Space International Regime," Annals of Air and Space Law (Toronto: Carswell Company Limited, 1980), p. 549. 
The use of the common heritage concept in ocean and space law has contributed to a humanist trend in international law, a change in international law that theorists say is gradually occurring. This change is a shift from law as a way of policing nations and promoting military security to law as a way of promoting welfare concerns such as the environment, human advancement and anti-poverty. ${ }^{13}$ This trend is expected to continue as more small, developing nations push for greater recognition and greater influence on international law and economics. UNCLOS was the first treaty negotiation that brought together as large a number of the world's countries to discuss international law. Another trend that has been seen since UNCLOS is a gradual shift in world leadership from traditional powers such as the United States and Europe to other nations such as Japan.

The recent conference that brought together an even larger number of countries than UNCLOS was the 1992 United Nations Conference on Environment and Development in Rio de Janiero. One of the major issues at this conference was determining how to slow global deforestation. The issue pit the industrialized nations who advocate rain forest preservation against a number of poverty-stricken developing nations that look to their rain forests as economic mainstays and view their decisions about these forests as a sovereign right. The idea that nature in general and rain forests in particular are part of the

13. Edward McWhinney, D. Ross, G. Tunkin, eds., From Coexistence to Cooperation: International Law and Organization in the Post-Cold War Era (Boston: Martinus Nijhoff Publishers, 1991). 
common heritage of humankind underlies the argument of a number of nations that want to participate in decisions about these valuable resources. The phrase common heritage has been used in newspaper articles and applied to rain forests to describe one of the central issues of the conference. ${ }^{14}$

The global visionaries - represented most vocally by the nongovernmental environmental organizations - are once again urging that nature be considered the common heritage of humankind and be protected for this and future generations by a cooperative international treaty. Although resources such as rain forests may never be declared the common heritage in international law, the fact that people view them as such may increase the chance they will receive some global protection. The environment - atmosphere, oceans and forests - is the new global issue that demands cooperation as seabed mining demanded it in the 1970s. These resources are much less obscure than minerals on the floor of the ocean and there is a greater chance that international policy will be devised for environmental protection. The Third World has a much better bargaining position to get demands of aid and technology transfer in environmental diplomacy than it did with seabed mining. In the 1970s, the Third World played on the guilt of developed nations when it tried to promote cooperation, technology transfers and developed nation-funding of seabed mining. The Third World needed to be given the technology to

14. Marlise Simons, "North-South Divide Marring Environment Talks," New York Times (March 17, 1992): p. A8. 
participate in such an economic enterprise. Today, the Third World can demonstrate that the developed countries are responsible for much of the environmental degradation to the atmosphere. The Third World can use this scientific arguments to demand technology that will help its nations curb environmental problems that might accompany development. The Third World also controls much of the world's rain forests. This gives these nations leverage in negotiations about preserving these forests. 15

As far as the oceans are concerned, the concept of the common heritage rules the seabed by default. Developed countries do not have the interest to engage in seabed mining. When and if there is economic demand for the seabed minerals, the common heritage concept will probably continue to dictate the way both developed and developing nations engage in the activity. At this point, the developed nations may see a need to resolve the more technical disagreements in the treaty and may then join it. Until then, the idea of including the nations of the world in the management of a global commons remains a goal that internationalists will continue to preach in marine policy as well as global environmental policy.

There is a need for this type of idealism even if it never translates into concrete policy. It has an effect on policy and contributes to larger trends in international relations. The idea of the common heritage is unlikely to galvanize people from

15. Paul Lewis, "Negotiations in Rio Agree to Increase Aid to Third World," New York Times (14 June 1992): p. 1, sect. 1. 
different nations in the way it did briefly at the end of the 1960s, however, there is a chance that leadership from people who do not fall into ideological camps could succeed in international ocean affairs. 


\section{APPENDIX \\ NAMES OF PERSONS INTERVIEWED}

Elisabeth Mann Borgese, founder of the International Ocean Institute and former delegate from Austria to the Third United Nations Conference on the Law of the Sea. Halifax, Canada, 1 November 1991. Correspondence, 12 February 1992.

Marne Dubs, manager of Kennecott Consortium's manganese nodule, former advisor to the U.S. delegation to UNCLOS.

Narragansett, RI, 23 July 1991.

Miriam Levering, Ocean Education Project, correspondence, 4 October 1991.

Dolliver Nelson, Executive Secretary of the Preparatory Commission, Law of the Sea Office for the U.N. Secretariat. Telephone interview, 20 May 1992.

Arvid Pardo, former Ambassador to the United Nations from Malta. Telephone interview, 2 December 1991 and correspondence, 11 February 1992.

Senator Claiborne Pell, Rhode Island's U.S. Senator. Telephone interview, 2 December 1991.

Elliot Richardson, former Ambassador-at-Large, Special Representative of the President for the Law of the Sea and currently a senior partner at Milbank, Tweed, Hadley \& McCloy. Telephone interview, 7 May 1992

Barbara Weaver, United Methodist Church, Women's Division Board of Global Ministries, formerly a member of the Neptune Group and the Methodist Church Law of the Sea Project. New York City, 20 September 1991. 


\section{Bibliography}

Agar, H., Aydelotte, F. Borgese, G.A. et al. The City of Man: A Declaration on World Democracy. New York: The Viking Press, 1940.

Agarwala, P.N. The New International Economic Order: An Overview. New York: Pergamon Press, 1983.

Alexander, Lewis M. Navigational Restrictions Within the New LOS Context: Geographical Implications for the United States. Peacedale, RI: Offshore Consultants Inc., 1986. , ed. Needs and Interests of the Developing

Countries. Kingston, R.I., 1973. . "The New Geography of the World's Oceans

Before and After the Law of the Sea." 15 Columbia Journal of World Business (1980): pp. 6-16. ed. International Rules and Organization

for the Sea: Proceedings of the Third Annual Conference of the Law of the Sea Institute, June-24-27, 1968.

Kingston, RI: The University of Rhode Island, 1968. Anand, R.P. The Legal Regime of the Sea-Bed and the Developing Countries. Delhi: Thomson Press Ltd., 1975. . Origin and Development of the Law of the Sea:

History of International Law Revisited. The Hague:

Martinus Nijhoff Publishers, 1983.

Ashmore, Harry S. Unseasonable Truths: The Life of Robert

Maynard Hutchins. Boston: Little, Brown and Company, 1989. 
Attard, David J. The Exclusive Economic Zone in International Law. Oxford: Clarendon Press, 1987.

Barnes, J. N. "Non-governmental organizations: Increasing the Global Perspective." 8 Marine Policy, (1984): pp. 171-81. Bennett, A. Leroy. International Organizations, Principles and Issues. Englewood Cliffs, NJ: Prentice Hall, 1977. Bhagwati, Jagdish, ed. The New International Economic Order:

The North-South Debate. Cambridge, MA: The MIT Press, 1977.

Biggs, Gonzalo. "Deep Seabed Mining and Unilateral Legislation." Ocean Development and International Law 8 (1980): pp. 223-257.

Black, Henry. Black's Law Dictionary, 5th Edition. St. Paul: West Publishing Co., 1979.

Boczek, Boleslaw. "Ideology and the Law of the Sea: The Challenge of the New International Economic Order. " Boston College International \& Comparative Law Review 7 (1979): pp. 1-30.

Borgese, Elisabeth Mann. "Boom, Doom, and Gloom Over the Oceans: The Economic Zone, the Developing Nations, and the Conference on the Law of the Sea." San Diego Law Review 11 (1974): pp. 541-556. . The Future of the Oceans. Montreal:

Harvest House, 1986. . "Law of the Sea: The Next Phase." 4 Third World Quarterly, (1982): pp. 598-718. 
- The Mines of Neptune: Minerals and

Metals From the Sea. New York: H.N. Abrams, 1985. ."The New International Economic Order

and the Law of the Sea." San Diego Law Review 14

(1977): pp. 584-596.

, ed. Pacem in Maribus. New York:

Dodd, Mead \& Company, 1972.

, et al., eds. The Tides of Change: Peace,

Pollution and Potential of the Oceans. New York:

Mason/Charter, 1975.

Borgese, Guiseppe A. Foundations of the World Republic.

Chicago: University of Chicago Press, 1953.

. Goliath: The March of Fascism. New York:

Viking Press, 1937.

Brewer, Sam Pope. "Malta Warns UN on Radioactive Pollution at

Sea." New York Times (2 November 1967): p. 12.

Bulajic, Milan. Principles of International Development Law.

Boston: Martinus Nijhoff Publishers, 1986.

Buzan, B. Seabed Politics. New York: Praeger, 1976.

Carson, Rachel. The Sea Around Us. New York: Oxford

University Press, 1951.

Churchill, R. R. , Lay, S.H., Nordquist, M. and Simmonds, K. R.,

eds. New Directions in the Law of the Sea, 11 vols. Dobbs

Ferry, NY: Oceana Publishers, 1973-81.

Council on Ocean Law. Oceans Policy News. 1988-1992.

Dolman, A., ed. Global Planning and Resource Management. New

York: Pergamon Press, 1980. 
Doty, Robert C. "Pope Paul Calls for Urgent Steps to Aid Poor Lands." New York Times (29 March 1967): p. 1.

Dubs, Marne. "Minerals of the Deep Sea: Myth and Reality." In Pontecorvo, G., ed.,The New Order of The Oceans. New York: Columbia University Press, 1986.

Effective Use of the Sea: Report of the Panel on Oceanography

of the President's Science Advisory Committee.

Washington, D.C.: U.S. Government Printing Office, 1966.

Fincham, C. and William van Rensburg. Bread Upon The Waters:

The Developing Law of the Sea. Montreal: Turtledove Publishing, 1980.

Gilbert, F. The End of the European Era, 1890 to the Present.

New York: W.W. Norton \& Company, 1979.

Goldwin, Robert A. "Locke and the Law of the Sea."

Commentary 171 (June 1981): pp. 46-50.

Hayashi, Moritaka. "Registration of the First Group of Pioneer

Investors by the Preparatory Commission for the

International Sea-Bed Authority and for the International

Tribunal for the Law of the Sea." Ocean Development and International Law 20 (1989): pp. 1-33.

Hollick, Ann L. "Seabeds Make Strange Policy." 9 Foreign Policy, (1972-3): pp. 148-70.

.U.S. Foreign Policy And The Law of the Sea.

Princeton: Princeton University Press, 1981.

Hollick, Ann L. and Robert E. Osgood. New Era of Ocean Politics.

Baltimore: Johns Hopkins University Press, 1974. 
Johnston, J.L. "The Economics of the Common Heritage." 13

Marine Technology Society Journal (1979): pp. 26-32.

Joyner, Christopher. "Legal Implications of the Concept of the

Common Heritage of Mankind." International and

Comparative Law Quarterly 35 (1986): pp.190-199.

Juda, Lawrence. Ocean Space Rights: Developing U.S. Policy. New

York: Praeger Publishers, 1975.

, ed. The Seventh Session of the Third United

Nations Conference on the Law of the Sea: Summary

Remarks of the Speakers. 11 April-9 May 1978.

"UNCLOS-III and the New International

Economic Order." Ocean Development and International

Law 7 (1979): pp. 221-256.

Kimball, Lee. "Turning Points in the Future of Deep Seabed

Mining," Ocean Development and International Law 17: (1986), pp. 367-98.

King, Lauriston R. and Feenan D. Jennings. "The Executive and the Oceans: Three Decades of United States Marine Policy." Marine Technology Society Journal 22 (1988): pp. 17-32.

Larschan, B. and Brennan, B.C. "The Common Heritage of Mankind Principle in International Law," 21 Columbia Journal of Transnational Law, (1983), pp. 305-37.

Laursen, F. ed. Towards a New International Marine Order The Hague: Nijhoff, 1982.

Lewis, Paul. "Negotiations in Rio Agree to Increase Aid to Third World." New York Times (14 June 1992): p.1. 
Logue, John, ed. The Fate of the Oceans. Villanova: World Order Research Institute, 1972.

Mahmoudi, Said. The Law of Deep Sea-Bed Mining. Stockholm:

Almqvist \& Wiksell International, 1987.

Malone, J. "Who Needs the Sea Treaty?" Foreign Policy 54: (1984), pp. 44-64.

McWhinney, Edward, et al., eds. From Coexistence to

Cooperation: International Law and Organization in the

Post Cold-War Era. Boston: Martinus Nijhoff Publishers, 1991.

Mero, John. The Mineral Resources of the Sea. Amsterdam:

Elsevier, 1965.

Nesgos, Peter D. "The Proposed International Sea-Bed Authority as a Model for the Future Outer Space International Regime." Annals of Air and Space Law. Toronto: Carswell Company Limited, 1980.

Nordquist, Myron H. and Choon-ho Park, eds. Reports of the United States Delegation to the Third United Nations Conference on the Law of the Sea, Occasional Paper No. 33. Honolulu: the Law of the Sea Institute, University of Hawaii, 1983.

Oda, Shigeru, ed. The International Law of the Ocean Development: Basic Documents. Leyden: Sijthoff, 1972. ed. The Law of the Sea in Our Time: The United

Nations Sea-bed Committee, 1968-1973. Leyden: Sijthoff, 1977.

Ogley, R. Internationalizing the Seabed. Aldershot: Gower, 1984. 
Our Nation and The Sea: A Plan for National Action.: Report of the Commission on Marine Science, Engineering and Resources. Washington, D.C.: U.S. Government Printing Office, 1969.

Oxman, Bernard. "The Third United Nations Conference on the Law of the Sea: the 1974 Caracas Session - the Tenth Session." American Journal of International Law, volumes 69-76. (1975-1982).

Oxman, Bernard H., D. Caron and C. Buderi, eds. Law of the Sea: U.S. Policy Dilemna. San Francisco: Institute for Contemporary Studies, 1983.

Padan, John W. "Commerical Recovery of Deep Seabed Manganese Nodules: Twenty Years of Accomplishments." Marine Mining 9, (1990): pp.87-103.

Pardo, Arvid. The Common Heritage: Selected Papers on Oceans and World Order, 1967-1974. Malta: Malta University Press, 1975. . "The Convention on the Law of the Sea: A Preliminary Appraisal." San Diego Law Review 20 (April 1983): 489-503. . "An International Regime for the Deep Seabed:

Developing Law or Developing Anarchy." The Texas International Law Forum 5 (1969): pp. 204-217. - "A Statement on the Future Law of the Sea in

Light of Current Trends in Negotiations." Ocean Development and International Law 1. (1974): p. 320. 

."Who Will Control the Seabed?" 47 Foreign Affairs, (1968), pp. 123-37.

Pardo, A. \& Borgese. The New International Economic Order and the Law of the Sea. Malta: International Ocean Institute, 1976.

Pendley, W.P. "The US Will Need Seabed Minerals." 25 Oceanus, (1982): pp. 12-17.

Perlez, Jane. "Stranded by Superpowers, Africa Seeks an Identity." New York Times (17 May 1992): p. 1.

Pinto, M.C.W. "The Developing Countries and the Exploitation of the Deep Seabed." The Columbia Journal of World Business (Winter 1980): pp. 30-41.

Puchala, Donald J. and Stuart I Fagan. "International Politics in the 1970s: the Search for a Perspective." International Organization 28 (1974): pp. 247-266.

Ratiner, L. S. "United States Oceans Policy: An Analysis," 2 Journal of Maritime Law and Commerce (1971): pp. 22566.

Reubens, Edwin, ed. The Challenge of the New International Economic Order. Boulder: Westview Press, 1981.

Richardson, Elliot. "Law of the Sea: A Reassessment of U.S. Interests." Mediterranean Quarterly 1 (1990): pp. 1-13.

Richardson, Jacques, ed. Managing the Ocean. Mt. Airy, MD: Lomond Publications, 1985.

Saffo, Paul L. "The Common Heritage of Mankind: Has the General Assembly Created a Law to Govern Seabed Mining?" Tulane Law Review 53 (1979): pp. 492-520. 
Safire, William. "Very Deep Thoughts." New York Times (4 July 1977): p. 17.

Sandars, Thomas C., ed. The Institutes of Justinian. Westport, CT: Greenwood Press, 1922.

Schmidt, Markus G. Common Heritage or Common Burden?

Oxford: Clarendon Press, 1989.

Simons, Marlise. "North-South Divide Marring Environment Talks." New York Times (17 March 1992): p. A8.

Stone, Julius. Visions of World Order: Between State Power and Human Justice. Baltimore: The Johns Hopkins University Press, 1984.

Swing, John T. "Who Will Own the Oceans?" 54 Foreign Affairs (1976): pp. 527-546.

United Nations Conference on the Law of the Sea, Conventions on the High Seas and the Continental Shelf. 29 April 1958. Treaties and Other International Acts Series, 5200 and 5578.

United Nations Convention on the Law of the Sea (1982).

International Legal Materials, vol. XXI, no. 6, November B1982.

United Nations. General Assembly. Official Records. Document A/C.1/PV. 1515 and 1516. 1 November 1967.

United Nations. Note verbale. Document A/6695. 17 August 1967. - Report by the Secretariat of the United Nations Conference on Trade and Development. Implications of the Exploitation of the Mineral Resources of the 
International Area of the Sea-Bed: Issues of International Commodity Policy. TD/B/C.1/170. 8 Januaary 1975.

. Resolution 3281 (XXIX). 12 December 1974

. Resolution 3201 (S-VI). 1 May 1974.

. Resolution 3202 (S-VI). 1 May 1974.

. Resolution 2574D (XXIV). 15 December 1969.

. Resolution 2749 (XXV). 17 December 1970

. Official Records. Document A/PV.1833. 15

December 1969.

- Official Records. Report of the Committee on the

Peaceful Uses of the Sea-Bed and Ocean Floor Beyond the

limits of National Jurisdiction. Supplement 21. Document

A/8721: pp. 70-73.

. Law of the Sea. Document A/CONF. 62/C1/L6. 13

August 1974.

United States Code. Deep Seabed Hard Mineral Resources Act.

Public Law 96-283, 28 June 1980.

United States Congress. Hearings. House Committee on Interior and Insular Affairs, Subcommittee on Mines and Mining. Mineral Resources of the Deep Seabed. 94th Congress, 2nd sess., 18, 20 and 24 May 1976.

. House Committee on Foreign

Affairs. U.S. Policy and the Third U.N. Conference on the Law of the Sea. 97th Cong., 1st sess. 14 May 1981.

. House Committee on Foreign

Affairs, Subcommittees on International Economic Policy and Trade and on International Organizations. Deep 
Seabed Hard Mineral Resources Act, 96th Cong., 1st sess., 11 July 1979. - Senate Committee on Foreign

Relations. Deep Seabed Hard Minerals. 96th Cong, 1st sess., 13 June 1979. - Senate Committee on Foreign

Relations, Subcommittee on Arms Control, Oceans and International Environment. Deep Seabed Mineral Resources Act. 95th Cong., 2nd sess., 17 August 1978. - Senate Committee on Interior and Insular Affairs Subcommittee on Minerals, Materials and Fuels. Mineral Resources of the Deep Seabed, 93rd Cong., 1st sess., 17 May 1973.

U.S. Congress. House. Committee on International Relations. Report of Congressional Research Service on Deep Seabed Minerals: Resources, Diplomacy, and Strategic Interest. 95th Cong., 2nd sess., 1 March 1978.

U.S. Congress. Senate Report no. 96-307. Deep Seabed Mineral Resources Act, 96th Cong., 1st sess.

Vicuna, Francisco, ed. The Exclusive Economic Zone: A Latin American Perspective. Boulder, CO: Westview Press, 1984. von Glahn, Gerhard. Law Among Nations, 5th Edition. London:

Macmillan Publishing Co., 1986.

Weaver, Barbara, Kimball, Lee, et al. Voyage to Discovery:

Charting of the Sea. Unpublished loose-leaf manual on the Law of the Sea. 
Welling, Conrad G. "Mining of the Deep Seabed in the Year 2010," 45 Louisiana Law Review (1985), pp. 1249-67.

Wenk, E. The Politics of the Ocean. Seattle: University of Washington Press, 1972.

Wertenbaker, William. "A Reporter at Large: The Law of the Sea." New Yorker, 1 and 8 August 1983.

World Order Research Institute. World Order Research Institute Report. Issues from 1974-1979.

Zinsser, William, ed. Extraordinary Lives: The Art and Craft of American Biography. Boston: Houghton Mifflin Company, 1988. 